\title{
Vertical profiles of light absorption and scattering associated with black carbon particle fractions in the springtime Arctic above $79^{\circ} \mathrm{N}$
}

\author{
W. Richard Leaitch ${ }^{1}$, John K. Kodros ${ }^{2, a}$, Megan D. Willis ${ }^{3, b}$, Sarah Hanna ${ }^{4, c}$, Hannes Schulz ${ }^{5}$, Elisabeth Andrews ${ }^{6,8}$, \\ Heiko Bozem $^{7}$, Julia Burkart ${ }^{3, d}$, Peter Hoor ${ }^{7}$, Felicia Kolonjari ${ }^{9}$, John A. Ogren ${ }^{8}$, Sangeeta Sharma ${ }^{1}$, Meng Si ${ }^{4, e}$, \\ Knut von Salzen ${ }^{9}$, Allan K. Bertram ${ }^{4}$, Andreas Herber ${ }^{5}$, Jonathan P. D. Abbatt ${ }^{3}$, and Jeffrey R. Pierce ${ }^{2}$ \\ ${ }^{1}$ Environment and Climate Change Canada, Toronto, ON, Canada \\ ${ }^{2}$ Department of Atmospheric Science, Colorado State University, Fort Collins, CO, USA \\ ${ }^{3}$ Department of Chemistry, University of Toronto, Toronto, ON, Canada \\ ${ }^{4}$ Department of Chemistry, University of British Columbia, Vancouver, BC, Canada \\ ${ }^{5}$ Alfred Wegener Institute, Helmholtz Center for Polar and Marine Research, Bremerhaven, Germany \\ ${ }^{6}$ CIRES, University of Colorado, Boulder, CO, USA \\ ${ }^{7}$ Institute for Atmospheric Physics, Johannes Gutenberg University, Mainz, Germany \\ ${ }^{8}$ National Oceanic and Atmospheric Administration (NOAA), Boulder, CO, USA \\ ${ }^{9}$ Environment and Climate Change Canada, Victoria, BC, Canada \\ ${ }^{a}$ now at: Institute of Chemical Engineering Sciences (ICE), Foundation for Research and Technology (FORTH), \\ Patras, Greece \\ b now at: Lawrence Berkeley National Laboratory, Chemical Sciences Division, University of California - Berkeley, \\ Berkeley, CA, USA \\ ${ }^{c}$ now at: Environment and Climate Change Canada, Victoria, BC, Canada \\ ${ }^{d}$ now at: Aerosol Physics and Environmental Physics, Faculty of Physics, University of Vienna, Vienna, Austria \\ ${ }^{e}$ now at: Department of Physical and Environmental Sciences, University of Toronto Scarborough, Toronto, ON, Canada
}

Correspondence: W. Richard Leaitch (leaitchs@gmail.com) and Jeffrey R. Pierce (jeffrey.pierce@ colostate.edu)

Received: 1 September 2019 - Discussion started: 11 September 2019

Revised: 2 July 2020 - Accepted: 9 July 2020 - Published: 10 September 2020

\begin{abstract}
Despite the potential importance of black carbon (BC) for radiative forcing of the Arctic atmosphere, vertically resolved measurements of the particle light scattering coefficient $\left(\sigma_{\mathrm{sp}}\right)$ and light absorption coefficient $\left(\sigma_{\mathrm{ap}}\right)$ in the springtime Arctic atmosphere are infrequent, especially measurements at latitudes at or above $80^{\circ} \mathrm{N}$. Here, relationships among vertically distributed aerosol optical properties $\left(\sigma_{\mathrm{ap}}, \sigma_{\mathrm{sp}}\right.$ and single scattering albedo or SSA), particle microphysics and particle chemistry are examined for a region of the Canadian archipelago between 79.9 and $83.4^{\circ} \mathrm{N}$ from near the surface to $500 \mathrm{hPa}$. Airborne data collected during April 2015 are combined with groundbased observations from the observatory at Alert, Nunavut and simulations from the Goddard Earth Observing System (GEOS) model, GEOS-Chem, coupled with the TwOMoment Aerosol Sectional (TOMAS) model (collectively
\end{abstract}

GEOS-Chem-TOMAS; Kodros et al., 2018) to further our knowledge of the effects of $\mathrm{BC}$ on light absorption in the Arctic troposphere. The results are constrained for $\sigma_{\mathrm{sp}}$ less than $15 \mathrm{Mm}^{-1}$, which represent $98 \%$ of the observed $\sigma_{\text {sp }}$, because the single scattering albedo (SSA) has a tendency to be lower at lower $\sigma_{\mathrm{sp}}$, resulting in a larger relative contribution to Arctic warming. At $18.4 \mathrm{~m}^{2} \mathrm{~g}^{-1}$, the average BC mass absorption coefficient (MAC) from the combined airborne and Alert observations is substantially higher than the two averaged modelled MAC values (13.6 and $9.1 \mathrm{~m}^{2} \mathrm{~g}^{-1}$ ) for two different internal mixing assumptions, the latter of which is based on previous observations. The higher observed MAC value may be explained by an underestimation of $\mathrm{BC}$, the presence of small amounts of dust and/or possible differences in $\mathrm{BC}$ microphysics and morphologies between the observations and model. In comparing the observations and sim- 
ulations, we present $\sigma_{\mathrm{ap}}$ and SSA, as measured, and $\sigma_{\mathrm{ap}} / 2$ and the corresponding SSA to encompass the lower modelled MAC that is more consistent with accepted MAC values. Median values of the measured $\sigma_{\mathrm{ap}}, \mathrm{rBC}$ and the organic component of particles all increase by a factor of $1.8 \pm 0.1$, going from near-surface to $750 \mathrm{hPa}$, and values higher than the surface persist to $600 \mathrm{hPa}$. Modelled $\mathrm{BC}$, organics and $\sigma_{\mathrm{ap}}$ agree with the near-surface measurements but do not reproduce the higher values observed between 900 and $600 \mathrm{hPa}$. The differences between modelled and observed optical properties follow the same trend as the differences between the modelled and observed concentrations of the carbonaceous components (black and organic). Model-observation discrepancies may be mostly due to the modelled ejection of biomass burning particles only into the boundary layer at the sources. For the assumption of the observed MAC value, the SSA range between 0.88 and 0.94 , which is significantly lower than other recent estimates for the Arctic, in part reflecting the constraint of $\sigma_{\mathrm{sp}}<15 \mathrm{Mm}^{-1}$. The large uncertainties in measuring optical properties and $\mathrm{BC}$, and the large differences between measured and modelled values here and in the literature, argue for improved measurements of $\mathrm{BC}$ and light absorption by BC and more vertical profiles of aerosol chemistry, microphysics and other optical properties in the Arctic.

\section{Introduction}

Aerosol particles responsible for Arctic haze (Mitchell, 1956) originate from midlatitude pollution sources during winter and spring (e.g. Holmgren et al., 1974; Rahn et al., 1977; Rahn, 1981; Shaw, 1983; Barrie and Hoff, 1985; Radke et al., 1984; Schnell and Raatz, 1984; Barrie, 1986). During late spring and summer, the Arctic is cleansed of haze particles by increased levels of precipitation (e.g. Garrett et al., 2011), resulting in a much cleaner, sometimes pristine, troposphere. At lower altitudes, Europe and northern Asia are thought to be the dominant source regions of Arctic haze, with contributions from south and/or central Asian sources dominating at higher altitudes (e.g. Stohl, 2006; Fisher et al., 2011; Sharma et al., 2013; Qi et al., 2017; Xu et al., 2017). Although surface-based concentrations of Arctic haze components have declined since studies of Arctic haze first began (Heidam et al., 1999; Sirois and Barrie, 1999; Sharma et al., 2004; 2006; Quinn et al., 2009; Hirdman et al., 2010; Sinha et al., 2017), it is unclear how total atmospheric burdens have changed (e.g. Sharma et al., 2013), and horizontal inhomogeneities with scales of 50-100 km (Hansen and Rosen, 1985) complicate this issue.

Radiative forcing by Arctic haze particles may be an important regional driver of Arctic climate change (e.g. Law and Stohl, 2007; Quinn et al., 2008). Characterised by a unimodal number distribution centred between 200 and $300 \mathrm{~nm}$ diameter (e.g. Bigg, 1980; Heintzenberg, 1980; Radke et al., 1984; Leaitch et al., 1989; Staebler, 1994), the effectiveness of Arctic haze particles at scattering light (e.g. Delene and Ogren, 2002; Schmeisser et al., 2017) is one reason why the net effect of the Arctic aerosol has been estimated to cool the Arctic atmosphere (Najafi et al., 2015; Navarro et al., 2016). Black carbon (BC) is the primary anthropogenic lightabsorbing component of Arctic haze (e.g. Leighton, 1983; Valero et al., 1984; Hansen and Rosen, 1984; Blanchet and List, 1987; Valero et al., 1989; Pueschel and Kinne, 1995; Hansen and Nazarenko, 2004; Flanner et al., 2007; McConnell et al., 2007; Law and Stohl, 2007; Quinn et al., 2008; Schindell and Faluvegi, 2009; Brock et al., 2011). Mitigation of $\mathrm{BC}$ emissions has been proposed as a provisional means of slowing Arctic warming (Shindell and Faluvegi, 2008; Kopp and Mauzerall, 2010; Stohl et al., 2015; Sand et al., 2016), but considerable uncertainty surrounds radiative forcing by $\mathrm{BC}$ in the Arctic. Despite profiles of black carbon and optical properties in recent years (e.g. Brock et al., 2011; McNaughton et al., 2011; Schwarz et al., 2010; Spackman et al., 2010; Wofsy et al., 2011; Ferrero et al., 2016; Markowicz et al., 2017), there remains a shortage of such observational data that limit evaluation of models of Arctic BC and light absorption (e.g. Samset et al., 2013) because the Arctic is subject to transport from many pollution sources at southern latitudes during winter and spring, and variability exists in altitude, both in location and from year to year.

Here, we use a combination of airborne and ground-based observations plus modelling to examine particle light scattering coefficients $\left(\sigma_{\mathrm{sp}}\right)$, light absorption coefficients $\left(\sigma_{\mathrm{ap}}\right)$ and single scatter albedos (SSAs) at the green wavelength of $550 \mathrm{~nm}$, from near the surface to $500 \mathrm{hPa}$, over a region of the Arctic Ocean between 79.9 and $83.4^{\circ} \mathrm{N}$. Recent Arctic studies, ground-based and airborne, indicate SSA values ranging from 0.92 to 0.97 during the month of April for a wavelength of $550 \mathrm{~nm}$ (Delene and Ogren, 2002; Brock et al., 2011; McNaughton et al., 2011; Schmeisser et al., 2017), which means that roughly $5 \%$ of the light incident on a population of Arctic haze particles is absorbed. The present work, part of the Canadian Network on Climate and Aerosols: Addressing Key Uncertainties in Remote Canadian Environments (NETCARE), contributes knowledge concerning Arctic optical properties and warming of the Arctic lower troposphere by BC during April at higher latitudes.

Airborne measurements of $\sigma_{\mathrm{ap}}$ that are based on the transmission of light through a filter, as used here, are constrained by instabilities during changes in pressure (i.e. altitude) and generally higher detection limits (DLs) associated with flight conditions. To reduce the skewness of observations imposed by these constraints, we expand our data set of $\sigma_{\text {ap }}$ values by employing a linear relationship between measured $\sigma_{\text {ap }}$ and the refractory black carbon mass concentrations (rBC) of Schulz et al. (2018). This approach enables a more comprehensive representation of values below DLs. In the airborne component of this data set, over $98 \%$ of $1 \mathrm{~min} \mathrm{av-}$ 
erages of $\sigma_{\mathrm{sp}}$ exceeding detection limit $\left(0.9 \mathrm{Mm}^{-1}\right)$ are below $15 \mathrm{Mm}^{-1}$. By constraining the discussion to values of $\sigma_{\mathrm{sp}}$ less than $15 \mathrm{Mm}^{-1}$, we address the largest component of Arctic haze, exclusive of the direct influence from strong plumes. Since most Arctic pollution in April is from longrange transport, the lower $\sigma_{\text {sp }}$ suggests that these particles, on average, spent longer times in the Arctic atmosphere and thus are more indicative of the "chronic" Arctic haze discussed by Brock et al. (2011). Furthermore, the SSAs for particle populations that fall within this constraint have been found to decrease more sharply with decreasing $\sigma_{\mathrm{sp}}$ (e.g. Targino et al., 2005; Andrews et al., 2011), making these populations more efficient at warming the atmosphere. Our primary objective is to demonstrate the large uncertainty in our knowledge of the absorption by $\mathrm{BC}$ at lower $\sigma_{\mathrm{sp}}$ in an area of the high Arctic with a low frequency of observations. Details of the methods employed are described in Sect. 2. In Sect. 3, results are presented, and vertical profiles of $\sigma_{\text {ap }}$ and SSAs are compared with simulated values. Section 4 is a broader discussion of the results, and conclusions are given in Sect. 5.

\section{Methods}

\subsection{Observations overview}

A total of 10 research flights were conducted in the Arctic using the Alfred Wegener Institute (AWI) Polar 6 aircraft, beginning on 5 April 2015 and ending on 21 April 2015. The first and only flight from Longyearbyen, Svalbard, Norway, is not discussed here as it was used to correct some instrument and sampling issues. Subsequently, four flights were conducted from Alert, Nunavut, Canada, during 7-9 April (two flights on 8 April), two flights from Eureka, Nunavut, Canada (11 and 13 April), and three flights from Inuvik, Northwest Territories (NWT), Canada, on 20-21 April (two flights on 20 April). Tracks of the flights out of Alert and Eureka can be found in Kodros et al. (2018), Schulz et al. (2018) and Willis et al. (2018). The flights out of Inuvik were conducted within a $300 \mathrm{~km}$ radius of Inuvik $\left(68.4^{\circ} \mathrm{N}, 133.7^{\circ} \mathrm{W}\right)$. Sampling of submicron particles from the Polar 6 during NETCARE is discussed by Leaitch et al. (2016), Schulz et al. (2018) and Willis et al. (2018). All airborne and model data presented here are referenced to a temperature of $20^{\circ} \mathrm{C}$ and pressure of $1013.25 \mathrm{hPa}$. The Polar 6 data are restricted to between $2 \mathrm{~min}$ after takeoff and $2 \mathrm{~min}$ prior to landing to avoid local contamination.

Ground-based observations of $\sigma_{\mathrm{sp}}, \sigma_{\mathrm{ap}}$, refractory $\mathrm{BC}$ $(\mathrm{rBC})$ and particle microphysics are routinely conducted at the Dr. Neil Trivett Global Atmosphere Watch Observatory at Alert, Nunavut $\left(82.5^{\circ} \mathrm{N}, 62.5^{\circ} \mathrm{W}\right)$. The site is approximately $7 \mathrm{~km}$ southeast of the main Alert station that is operated by the Canadian Department of National Defense. The impact of the camp on observations at the Alert observatory (hereafter, referred to as Alert) has been found to be insignif- icant for particles larger than about $50 \mathrm{~nm}$ diameter (Leaitch et al., 2018), and the observations are filtered for air arriving from within a $45^{\circ}$ arc centred on the station. The Alert optical properties data reported here are for particles less than $1 \mu \mathrm{m}$ diameter.

\subsection{Aerosol optical measurements}

Particle light scattering coefficients $\left(\sigma_{\mathrm{sp}}\right)$ at wavelengths of 450,550 and $700 \mathrm{~nm}$ were measured with a TSI Incorporated model 3563 three-wavelength volume-integrating nephelometer on the Polar 6 and at Alert. To account for the absence of a forward-scattering measurement where the collimated light beam is dumped (i.e. truncation of the total scattering between $0-7$ and $170-180^{\circ}$ ), the correction described by Anderson and Ogren (1998) was applied. A span check of the nephelometer calibration is routinely performed at Alert using $\mathrm{CO}_{2}$, and span checks of the nephelometer used on the Polar 6 were conducted before and after the study.

Values of $\sigma_{\text {ap }}$ at Alert are derived from a three-wavelength particle soot absorption photometer (PSAP), as discussed by Sharma et al. (2017). The $\sigma_{\text {ap }}$ on the Polar 6 were measured using a continuous light absorption photometer (CLAP), a three-wavelength filter-based instrument operating at 467 , 528 and $652 \mathrm{~nm}$. Based on the PSAP design, the CLAP, designed and built by the National Oceanic and Atmospheric Administration (NOAA), samples consecutively on one of eight spots on one $47 \mathrm{~mm}$ glass fibre filter (Pallflex E70$2075 \mathrm{~W}$ ), which improves functionality in situations where filter changes are more difficult, such as remote sites and aircraft (Ogren et al., 2017). For both the PSAP and CLAP, the $\sigma_{\mathrm{ap}}$ are derived from the change in light transmission through a spot on the filter, accumulating particles relative to light transmission through a reference spot. Both the PSAP and CLAP data were corrected for multiple scattering arising from the filter medium and accumulating particles using an empirical algorithm described by Bond et al. (1999) and Ogren (2010). To avoid artifacts associated with filter disturbances due to rapid pressure fluctuations, the Polar 6 absorption data are limited to in-flight pressure variations, as recorded within the nephelometer, of less than $2 \mathrm{hPa}$ over a 2 min period, encompassing each 1 min sample. Recently, Düsing et al. (2019) found that changes in water uptake by filter material used in particle absorption measurements can influence the light absorption measurement. In the present case, because the ambient temperatures were $-20^{\circ} \mathrm{C}$ or colder and the temperatures at the intake of the nephelometer, which was situated next to the CLAP, ranged from +14 to $+30^{\circ} \mathrm{C}$, we expect little influence from relative humidity on our results. As discussed in Sect. 3.2, in some circumstances these corrections may fail to correct overestimates of $\sigma_{\text {ap }}$ due to multiple scattering (Cappa et al., 2008a, b; Lack et al., 2008; Sinha et al., 2017).

The estimated detection limits (DLs) for $\sigma_{\mathrm{ap}}$ and $\sigma_{\mathrm{sp}}$ on the Polar 6 are 0.75 and $0.9 \mathrm{Mm}^{-1}$, respectively, at $550 \mathrm{~nm}$ 
wavelength and for 1 min averages. The DLs are calculated from the maximum of 2 times the standard deviation of the raw measurement during in-flight zeroes, which are also constrained to pressure variations of $2 \mathrm{hPa}$ or less. The $\sigma_{\mathrm{sp}} \mathrm{DL}$ was adjusted for the truncation correction, and the $\sigma_{\text {ap }}$ DL was adjusted for multiple scattering. Of approximately 2000 $1 \mathrm{~min}$ averaged data points collected over nine flights, 220 absorption data points remain, mostly after scrutiny for pressure variations, followed by the removal of remaining points below DLs. Uncertainties in the Polar $6 \sigma_{\text {ap }}$ are considered in Sect. 3.3.

The DLs for $\sigma_{\mathrm{ap}}$ and $\sigma_{\mathrm{sp}}$ measured at Alert are $0.1 \mathrm{Mm}^{-1}$ and $0.4 \mathrm{Mm}^{-1}$, respectively, and represent DLs for the $1 \mathrm{~h}$ averages of Alert data used here. Based on Sherman et al. (2015) and Ogren et al. (2017), uncertainties in $\sigma_{\text {ap }}$ at $1 \mathrm{Mm}^{-1}$ and $\sigma_{\mathrm{sp}}$ at $10 \mathrm{Mm}^{-1}$ are $60 \%$ and $24 \%$, respectively. After discriminating for local influences and removal of compromised data (e.g. zeroes), the Alert data set comprises $15051 \mathrm{~h}$ averages, or approximately $70 \%$ of the February-April 2015 time period. The months of February and March are included to broaden the comparison with the model results.

The $\sigma_{\text {ap }}$ from the Polar 6 and from Alert were adjusted to the nephelometer wavelengths assuming a $1 / \lambda$ relationship, and the $\sigma_{\mathrm{ap}}, \sigma_{\mathrm{sp}}$ and SSAs for both platforms are reported for wavelengths of $450 \mathrm{~nm}$ (blue), $550 \mathrm{~nm}$ (green) and $700 \mathrm{~nm}$ (red). The SSAs, given by $\sigma_{\mathrm{sp}} /\left(\sigma_{\mathrm{sp}}+\sigma_{\mathrm{ap}}\right)$, were calculated for the green values of $\sigma_{\mathrm{sp}}$ and $\sigma_{\mathrm{ap}}$.

\section{3 rBC and physical measurements}

Size distributions for particles with diameters in the range of 85-1000 nm were measured on the Polar 6 using an ultrahigh sensitivity aerosol spectrometer (UHSAS; Droplet Measurement Technologies); hereafter, all particle sizes are given as diameters. The UHSAS is a laser-based aerosol spectrometer. Checks of concentration and sizing were done with nearly monodisperse particles of ammonium sulfate. Details of the measurements used here are discussed by Schulz et al. (2018). The size distributions from the UHSAS are used to estimate submicron particle volume concentrations. Submicron particle volume concentrations at Alert are estimated from size distribution measurements with a TSI Incorporated 3034 scanning mobility particle sizer (SMPS) spectrometer, previously discussed by Leaitch et al. $(2013,2018)$. As discussed by Willis et al. (2018), size distributions from the UHSAS were compared with those from the TSI Incorporated 3034 SMPS at the Alert from four flights when the Polar 6 flew between 60 and $200 \mathrm{~m}$ above the ocean (sea ice) surface a few kilometres north of Alert. The volume concentrations calculated from the two measurements for the $85-500 \mathrm{~nm}$ size range compared within $20 \%$ for all flights.

Refractory black carbon (rBC) was measured on the Polar 6 using a Droplet Measurement Technologies single particle soot photometer (SP2). The SP2 detects individual particles using an intra-cavity Nd:YAG laser operating at $1064 \mathrm{~nm}$. Incandescence from components of particles absorbing at $1064 \mathrm{~nm}$ (i.e. BC) is detected by a pair of photomultiplier tubes, and the peak amplitude of the thermal radiation is proportional to the mass of refractory material (Moteki and Kondo, 2007; Slowik et al., 2007). The detection range of the SP2 used here is 0.60 to $330 \mathrm{fg} \mathrm{rBC}$ or approximately $85-700 \mathrm{~nm}$ mass equivalent diameter for an $\mathrm{rBC}$ density of $1.8 \mathrm{~g} \mathrm{~cm}^{-3}$ (Bond and Bergstrom, 2006; Bond et al., 2013). Mass calibrations are based on Fullerene soot particles that were size selected using a differential mobility analyzer. The mobility diameters were converted to $\mathrm{rBC}$ mass concentrations following Gysel et al. (2011). Schulz et al. (2018) describe the data set used here, and they estimate the uncertainty at $\pm 15 \%$. The $\mathrm{rBC}$ measurements conducted at Alert, also made using a SP2, are discussed by Sharma et al. (2017).

Non-refractory aerosol mass concentrations were measured aboard Polar 6 with an Aerodyne high-resolution timeof-flight aerosol mass spectrometer (ToF-AMS; DeCarlo et al., 2006). These measurements are described in detail by Willis et al. (2019). Briefly, the ToF-AMS measured nonrefractory aerosol between about 70 and $700 \mathrm{~nm}$ in vacuum aerodynamic diameter. Detection limits for sulfate and total organic aerosol, based on $10 \mathrm{~s}$ time resolution, were 0.01 and $0.08 \mu \mathrm{g} \mathrm{m}^{-3}$, respectively.

Coarse particles ( $>2 \mu \mathrm{m}$ diameter) on the Polar 6 were measured with a GRIMM model 1.129 optical particle counter. Model 1.129 measures particles larger than $0.25 \mu \mathrm{m}$, but only the coarse particle concentrations are used here. As shown by comparisons with a particle-measuring system model FSSP-300 probe operated under one wing of the Polar 6, the coarse particles tend to be sampled less effectively than the submicron particles, but they are still an indicator of the presence of coarse particles, and, more importantly, the coarse particles entering the Polar 6 sample manifold.

\subsection{Modelling}

The observations of $\sigma_{\mathrm{sp}}, \sigma_{\mathrm{ap}}$ and SSAs are compared to version 10.01 of the GEOS-Chem chemical-transport model (http://geos-chem.org, last access: 1 September 2020), driven by Modern-Era Retrospective analysis for Research and Applications (MERRA) reanalysis meteorology fields. The February-April 2015 simulation was preceded by a 2 month spin up. This version of GEOS-Chem uses a horizontal resolution of $4^{\circ}$ latitude by $5^{\circ}$ longitude (approximately $440 \mathrm{~km} \times 72 \mathrm{~km}$ in the flight region near Alert and Eureka and $440 \mathrm{~km} \times 200 \mathrm{~km}$ near Inuvik) with 47 vertical layers. Relevant to the observations presented here, 24 vertical layers cover the pressure region from the surface to $500 \mathrm{hPa}, 12$ of which are from the surface to $850 \mathrm{hPa}$, spaced equally by $15.5 \mathrm{hPa}$. Aerosol microphysics is simulated using the TwOMoment Aerosol Sectional (TOMAS) microphysics scheme (Adams and Seinfeld, 2002) coupled with GEOS-Chem (GEOS-Chem-TOMAS), including tracers for sulfate, BC, 
organic aerosol, sea salt, dust and aerosol water. More details are found in Adams and Seinfeld (2002), Lee et al. (2013), Lee and Adams (2012), and Kodros et al. (2018). Here, particle water is excluded from the calculations because the observed particles were relatively dry; during the flights, the outside air temperature was $-15^{\circ} \mathrm{C}$ or less, and the measured temperature of air entering the nephelometer, which was situated near the CLAP, ranged at $+14{ }^{\circ} \mathrm{C}$ or higher, indicating very low values of relative humidity at the point of measurement. Also, no significant particle water was indicated in the ToF-AMS data. Aerosol optical properties are calculated using monthly averaged aerosol mass and number concentrations with refractive indices from the Global Aerosol Data Set (GADS; Kopke et al., 1997). To calculate aerosol optical properties, we assume two of the BC mixing states discussed by Kodros et al. (2018): (1) "Allcore", in which BC is fully mixed with other chemical species in a core-shell morphology within each size section, where BC forms the core of the particle and hydrophilic aerosol species form a concentric shell around the BC core; (2) "Rshell", in which $\mathrm{BC}$ is mixed within a particle, again as a core surrounded by hydrophilic species, but the size-dependent fraction of BC-containing particles' core sizes and hydrophilic coating thicknesses are constrained by the observed sizes and the modelled BC mass concentration, as described by Kodros et al. (2018). These two states are illustrated in Fig. 2 of Kodros et al. (2018), where they are referred to as "rshell constrained" (Fig. 2b) and "allCoreShell" (Fig. 2d). Particle mass, including BC mass, is conserved. The Allcore state is less realistic because every particle contains a $\mathrm{BC}$ core, whereas Arctic observations identify BC in roughly $10 \%-$ $20 \%$ of the particles (e.g. Sharma et al., 2017). As a result, the Allcore mixing assumption overestimates absorption (e.g. Alvarado et al., 2016). Rshell, which is based on observations, has a smaller fraction of coating material participating in absorption enhancement, resulting in lower absorption compared with Allcore; Rshell absorption is higher than that of the externally mixed assumption (Kodros et al., 2018). The Mie code of Bohren and Huffman (1983) for two concentric spheres is used to calculate $\sigma_{\mathrm{spt}}, \sigma_{\mathrm{ap}}$ and SSAs.

Emissions are derived from the Emissions Database for Global Atmospheric Research (EDGAR) Hemispheric Transport of Air Pollution (HTAP) version 2.2 (JanssensMaenhout et al., 2015). Following Xu et al. (2017), BC and organic carbon emissions from gas flaring derived from the Evaluating the Climate and Air Quality Impacts of ShortLived Pollutants (ECLIPSE) emission inventory (Klimont et al., 2017) are included. Biomass burning emissions are from the Fire INventory from NCAR (FINN) for the year 2015 (Wiedinmyer et al., 2011), but the particles are only injected into the boundary layer in this case. Dust emissions follow the Dust Entrainment and Deposition (DEAD) model scheme (Zender et al., 2003), and sea salt aerosol emissions are based on Jaeglé et al. (2011). The model uses a refractive index for BC of $1.9+0.79 i$, as recommended by Bond

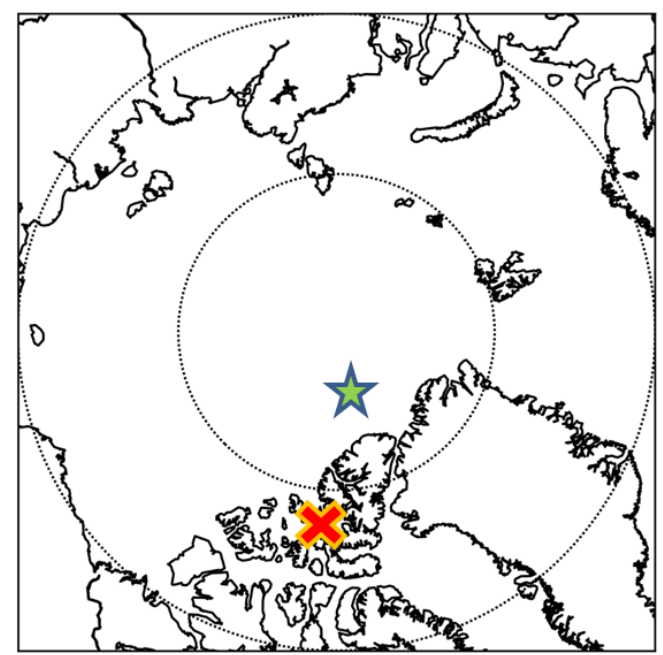

Figure 1. Map of the Arctic centred on the North Pole. Stars show centre of model grids used in this study. Green - northwest Alert (NW Alert) grid; orange - Axel grid. Grid sizes are approximately $440 \mathrm{~km}(\mathrm{~N}-\mathrm{S}) \times 72 \mathrm{~km}(\mathrm{E}-\mathrm{W})$.

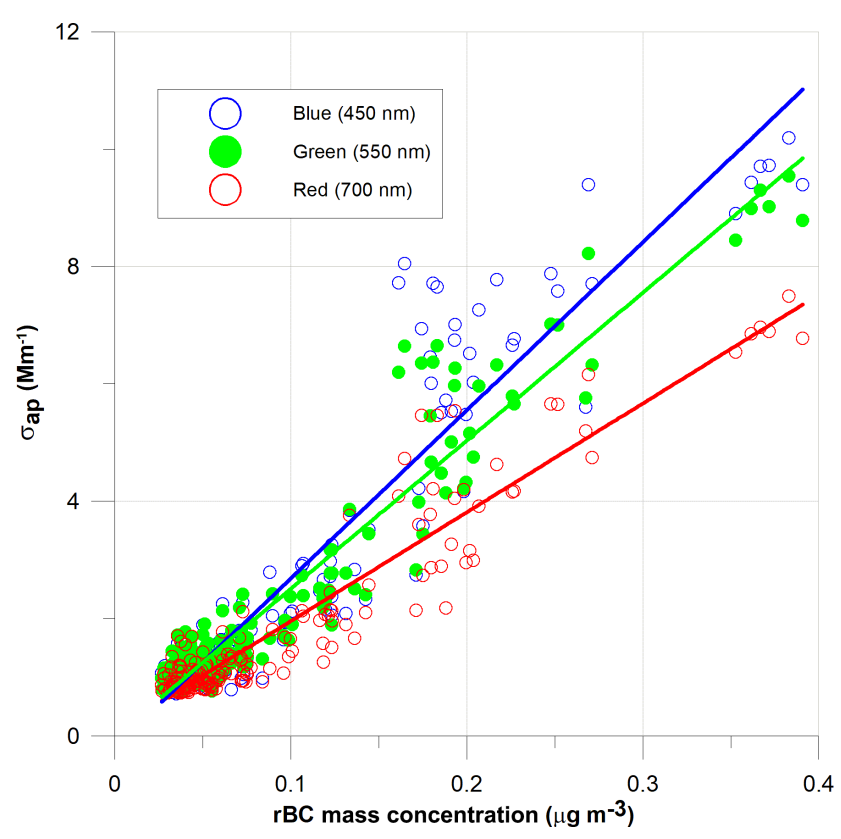

Figure 2. Particle light absorption coefficient $\left(\sigma_{\text {ap }}\right)$ at three wavelengths $(450,550$ and $700 \mathrm{~nm})$ plotted against the refractory black carbon (rBC) mass concentrations for all above-detection-limit data collected during Polar 6 flights from Alert, Nunavut, Eureka, Nunavut, and Inuvik, Northwest Territories (NWT). Regression lines are shown for reference.

and Bergstrom (2006). See Liu et al. (2020) for a review of the refractive index of $\mathrm{BC}$. The refractive index differs from the value of $1.75+0.45 i$ used by Kodros et al. (2018). That aside, details of the application of this version of the model to the Arctic, and a detailed discussion of the role of mixing state on absorption by BC, are given by Kodros et al. (2018). 
The data used here are from two vertical columns of the model as follows: one column includes Axel Heiberg Island and the Arctic Ocean west of the island; the second is all Arctic Ocean to the west and slightly north of Alert. Hereafter, the two grids are referred to as "Axel" and "NW Alert". They are centred on $78^{\circ} \mathrm{N}, 95^{\circ} \mathrm{W}$ and $86^{\circ} \mathrm{N}, 75^{\circ} \mathrm{W}$, respectively, as indicated by the stars in Fig. 1. The model grid that includes Alert is not used in order to avoid problems that might be associated with modelling of the significant terrain of Ellesmere Island.

\section{Results}

In Sect. 3.1, we identify the strongest influences of dust on the $\sigma_{\text {ap }}$ observed from the Polar 6. In Sect. 3.2, we consider the mass absorption coefficients (MACs) for BC based on the observations (Alert and Polar 6) and the model, including MACs at low BC mass concentrations. In Sect. 3.3, we present the profile data of $\mathrm{rBC}$, median $\sigma_{\mathrm{ap}}$, median SSAs, $\sigma_{\mathrm{sp}}$ and sulfate and organic mass concentrations and compare them with like quantities from the GEOS-Chem-TOMAS model. The regression between $\sigma_{\mathrm{ap}}$ and $\mathrm{rBC}$ is used to increase the number of $\sigma_{\mathrm{ap}}$ and SSA values from which the medians are derived, enabling the influence of values below DLs and during pressure changes to be better represented.

\subsection{Dust absorption}

Figure 2 shows the blue $(450 \mathrm{~nm})$, green $(550 \mathrm{~nm})$ and red $(700 \mathrm{~nm}) \sigma_{\text {ap }}$ plotted as a function of $\mathrm{rBC}$ for the nine Polar 6 flights. A number of points in the rBC range of 0.15 $0.3 \mu \mathrm{g} \mathrm{m}^{-3}$ lie well above their respective linear regression lines. Those points represent measurements from two of the flights conducted out of Inuvik in plumes above $3 \mathrm{~km}$, with trajectories that trace back over northern China and Mongolia. In Fig. 3, the scattering Ångström exponents for green and red wavelengths are plotted against the number concentrations of particles larger than $2 \mu \mathrm{m}$. The Inuvik points are identified separately from the Alert and Eureka points, and the coarse particle influence associated with the Inuvik points is evident. The pattern of the lower Angström exponent points $(<0.8)$ vs. the increasing number concentrations of coarse particles agrees with the results of Hallar et al. (2015) for Asian dust measured at a mountain top in Colorado and with our general knowledge of aerosol optical properties (e.g. Aryal et al., 2014; Clarke et al., 2007; Russell et al., 2010). We assume that the Inuvik points with a scattering Ångström exponent of less than 0.8 and coarse particle number concentrations greater than $0.5 \mathrm{~cm}^{-3}$ are strongly influenced by dust.

The SSAs from both the Polar 6 and Alert are plotted against $\sigma_{\mathrm{sp}}$ at $550 \mathrm{~nm}$, in Fig. 4. The Polar 6 points are from the Polar 6 CLAP and nephelometer measurements, and the dust-influenced points associated with the Inuvik flights are

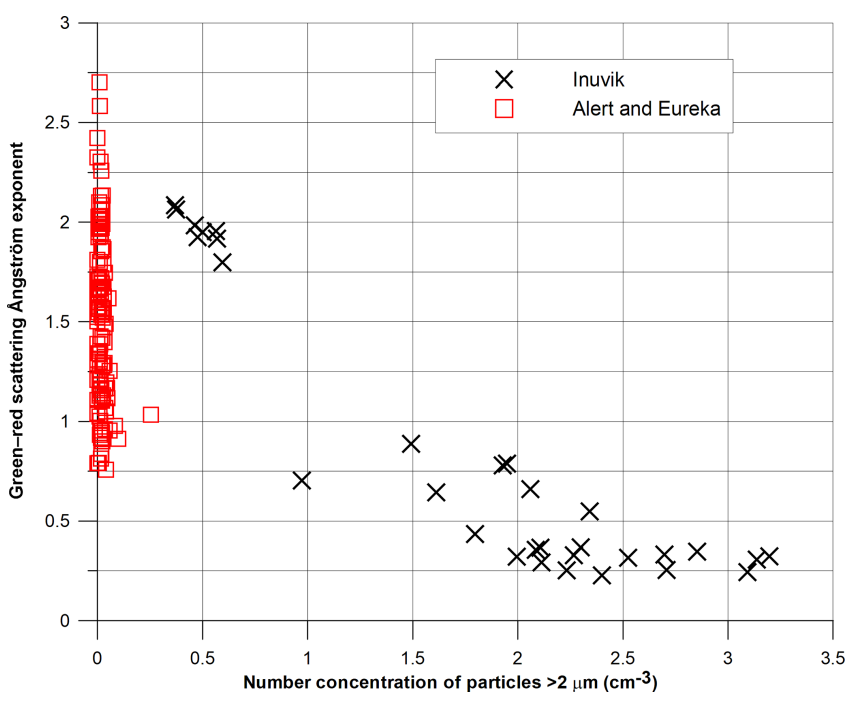

Figure 3. Light scattering Ångström exponent between green and red wavelengths plotted against the number concentrations of coarse particles ( $>2 \mu \mathrm{m}$ diameter). Data are separated between those collected during flights from Alert and Eureka (red boxes) and from Inuvik (black crosses).

highlighted. The Alert data cover the period from February to 14 April 2015, when the Polar 6 left that region. Alert data from February and March 2015 are included, in part to provide a larger comparison base with the model and in part to demonstrate consistency of the Polar 6 data with those from Alert, since the latter only reaches into the $0.75<\sigma_{\mathrm{ap}}<1.6 \mathrm{Mm}^{-1}$ region during February. As in previous observations (e.g Targino et al., 2005; Andrews et al., 2011; Schmeisser et al., 2018), lower values of SSAs are more frequent at these smaller $\sigma_{\mathrm{sp}}$. Hereafter, we only consider data that fall into the region of green $\sigma_{\mathrm{sp}}<15 \mathrm{Mm}^{-1}$, which represent $98 \%$ of the above DL Polar 6 data collected over Alert and Eureka and $85 \%$ of the above DL Alert data (February to 14 April, inclusive). With these constraints, strong contributions to $\sigma_{\text {ap }}$ from dust are removed. As next discussed, this improves the linear regression of $\sigma_{\mathrm{ap}}$ with rBC.

\subsection{Mass absorption}

The regression of $\sigma_{\mathrm{ap}}$ with $\mathrm{rBC}$ for the combined Polar 6 and Alert data (1-14 April), constrained as just discussed, has a slope of $18.4 \mathrm{~m}^{2} \mathrm{~g}^{-1}$ and intercept of +0.15 (Fig. 5). In Fig. 5, separate regressions through the Alert data and through the Polar 6 data overlap at a confidence level of greater than $95 \%$. The $\sigma_{\mathrm{ap}}-\mathrm{rBC}$ slope represents the average MAC of $\mathrm{rBC}$ in the measured particles, but this value is about twice that typically found for Arctic measurements at the green wavelength (e.g. $9.5 \mathrm{~m}^{2} \mathrm{~g}^{-1}$, McNaughton et al., 2011; $8 \mathrm{~m}^{2} \mathrm{~g}^{-1}$, Sharma et al., 2017; $9.8 \mathrm{~m}^{2} \mathrm{~g}^{-1}$, Zanatta et al., 2018). Modelled $\sigma_{\mathrm{ap}}$ are plotted against modelled $\mathrm{BC}$ for 


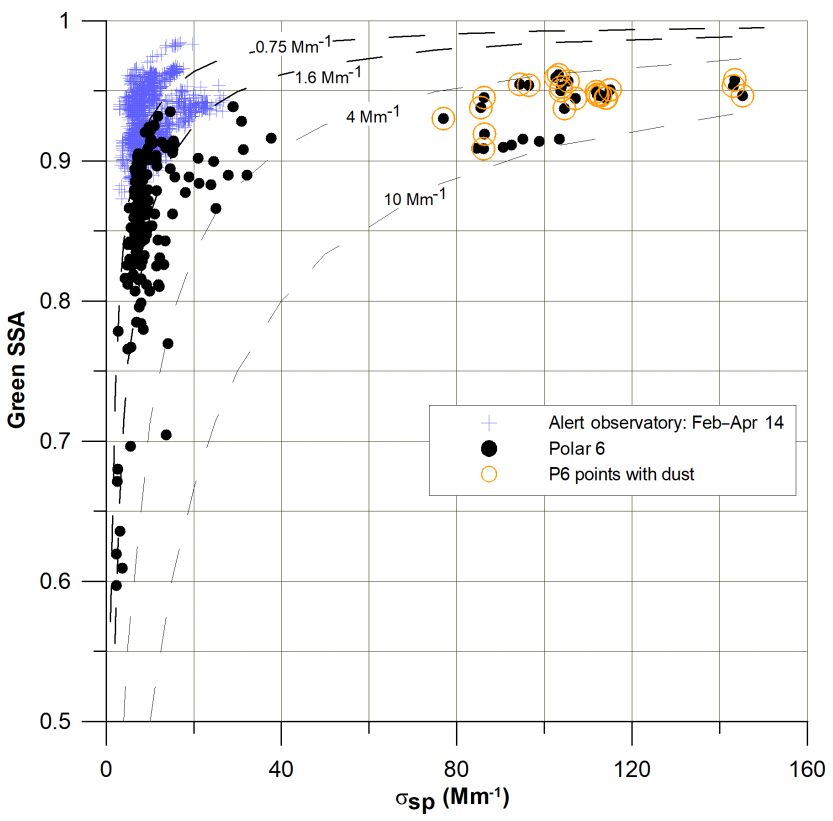

Figure 4. Single scattering albedo (SSA) at the green wavelength $(550 \mathrm{~nm})$ plotted against the particle light scattering coefficient $\left(\sigma_{\mathrm{sp}}\right)$ at $550 \mathrm{~nm}$. Data are separated between those collected at the Alert observatory (blue crosses) and those collected from the Polar 6 (P6) aircraft (black dots). In addition, points influenced most strongly by dust are circled in orange. Lines of equal particle light absorption $\left(\sigma_{\mathrm{ap}}\right)$ are for reference.

the NW Alert grid and Rshell mixing assumption in Fig. 6. These modelled values include a significant dust presence in many cases. We estimate the model MAC values for $\mathrm{BC}$ by constraining the dust concentrations to less than $0.2 \mu \mathrm{g} \mathrm{m}{ }^{-3}$, as shown by the black points in Fig. 6. For the case in Fig. 6, the MAC value for BC is $9.3 \mathrm{~m}^{2} \mathrm{~g}^{-1}$. The modelled MAC value for $\mathrm{BC}$ is estimated at $13.1 \mathrm{~m}^{2} \mathrm{~g}^{-1}$ for the NW Alert grid and Allcore mixing assumption. For the Axel grid, the estimated MAC value for $\mathrm{BC}$ is $8.8 \mathrm{~m}^{2} \mathrm{~g}^{-1}$ for the Rshell assumption and $14.0 \mathrm{~m}^{2} \mathrm{~g}^{-1}$ for the Allcore assumption. Due to a smaller influence of the coating material on absorption enhancement relative to the Allcore case, the lower Rshell results in a MAC value that is more consistent with those mentioned above.

We acknowledge that the model indicates a significant contribution from dust, and possibly other non-BC components, to atmospheric absorption in the Arctic. Average modelled profiles of the contributions to absorption from $\mathrm{BC}$ and non-BC absorbing components of particles, assuming an external mixture, are shown in Fig. 7 for the NW Alert grid box, split between particles less than $700 \mathrm{~nm}$ diameter and particles greater than $700 \mathrm{~nm}$ diameter. The nonabsorbing components include brown carbon and dust. For particles smaller than $700 \mathrm{~nm}$, the simulations suggest $\mathrm{BC}$ is, on average, the stronger absorbing component of the particles, with contributions from non-BC components approaching those from $\mathrm{BC}$

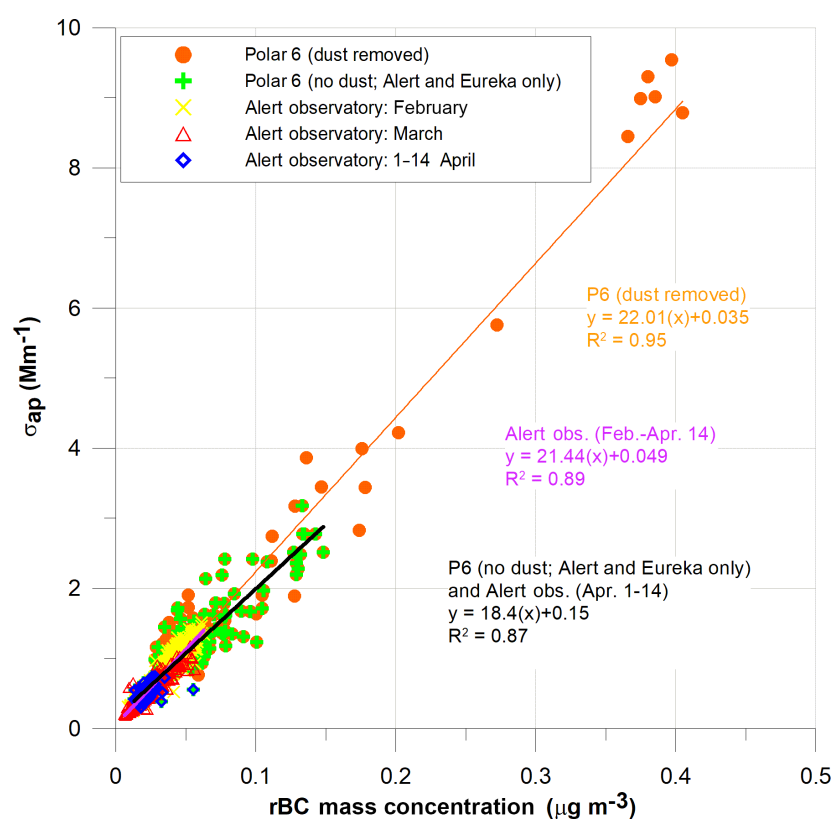

Figure 5. Particle light absorption coefficient $\left(\sigma_{\text {ap }}\right)$ at $550 \mathrm{~nm}$ plotted against refractory black carbon ( $\mathrm{rBC}$ ) mass concentrations for all above-detection-limit data collected during Polar 6 flights from Alert, Eureka and Inuvik, NWT, with major dust influence removed (orange dots), for data collected during Polar 6 flights from Alert and Eureka only (green crosses) and for data collected at the Alert observatory. The Alert observatory data are separated between those collected during February, March and 1-14 April, where the latter corresponds most closely with the Polar 6 flights out of Alert and Eureka. Regressions are shown for all Polar 6 data (major dust removed; orange curve), for all Alert observatory data (purple curve) and for the Polar 6 data from Alert and Eureka combined with the Alert observatory data for 1-14 April (black curve).

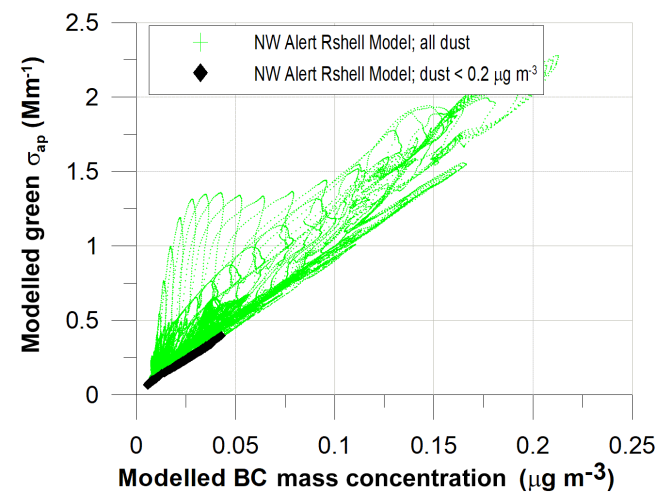

Figure 6. Modelled light absorption coefficients $\left(\sigma_{\mathrm{ap}}\right)$ at $550 \mathrm{~nm}$ plotted against black carbon (BC) mass concentrations for the NW Alert grid and the Rshell assumption (green). The black diamonds indicate the data limited to those points with dust concentrations less than $0.2 \mu \mathrm{g} \mathrm{m}^{-3}$ 


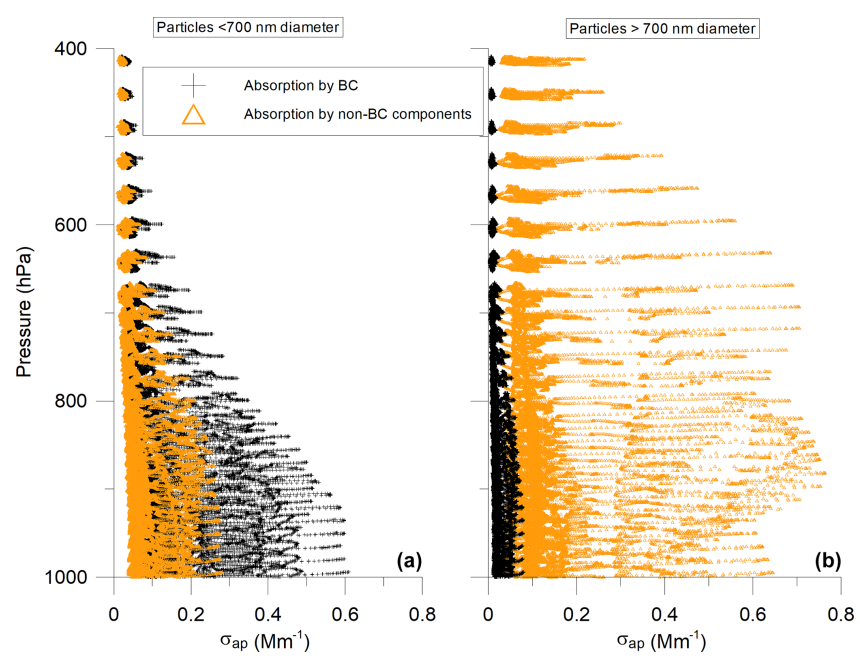

Figure 7. Modelled profile data of the contributions to absorption from BC (black crosses) and non-BC-absorbing components (orange triangles) for (a) particles less than $700 \mathrm{~nm}$ diameter and (b) particles $>700 \mathrm{~nm}$ diameter. The simulations are for the NW Alert grid box and based on an external mixture.

below 600 hPA. For particles larger than $700 \mathrm{~nm}$, absorption by non-BC components, primarily dust, dominates in this model. As shown in Fig. 3, there were relatively few coarse particles sampled from the Polar 6 in the regions around Alert and Eureka at any altitude, which represents a discrepancy between the observations and simulations.

The $\sigma_{\mathrm{ap}}-\mathrm{rBC}$ regressions of the observations and the simulations have positive intercepts (the standard error of the intercept for the Polar 6 plus Alert (1-14 April) fit, based on the measurement error, is 0.034 , and statistically, the intercept is greater than 0.1 at a confidence level of $>99 \%$ ). The intercept is due to increases in individual MAC values with decreasing concentrations of BC, as shown in Fig. 8a for the model and Fig. $8 \mathrm{~b}$ for the observations. In these plots, MACs should be constant across all $\mathrm{BC}$ if absorption is solely due to $\mathrm{BC}$ without enhancements from factors such as lensing or other absorbing components. The relative increases in absorption at lower BC will contribute to reduced SSA values at lower $\sigma_{\mathrm{sp}}$. The persistence of lower dust concentrations at low BC concentrations in the modelled MAC values (Fig. 8a) likely contributed to the increase in MACs at lower BC; as the $\mathrm{BC}$ concentrations decrease up to 100 times below the dust concentrations, absorption by dust, with its lower imaginary refractive index (0.0065 in the model), may approach absorption by $\mathrm{BC}$ and increase the apparent MACs for $\mathrm{BC}$. Because the modelled organic aerosol (OA) concentrations decrease proportionately with decreasing BC (Figs. 10 and $15)$ and the imaginary refractive index is lower $(0.0065)$, absorbing OA cannot explain the increase in the simulated MACs at lower BC. For the observations (Fig. 8b), smaller amounts of potentially absorbing dust also may be present at lower BC concentrations. The mass concentrations of coarse
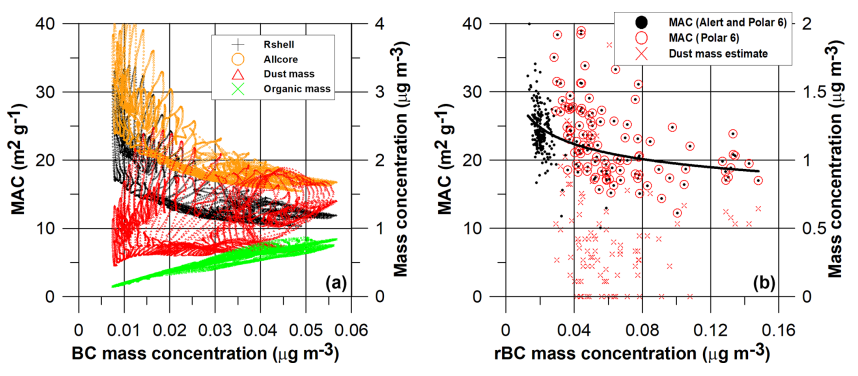

Figure 8. (a) Modelled BC mass absorption coefficient (MAC) plotted against modelled $\mathrm{BC}$ for the Allcore (orange circles) and the Rshell (black crosses) assumptions; modelled dust mass concentrations constrained to dust less than $1.5 \mu \mathrm{g} \mathrm{m}^{-3}$ vs. modelled BC mass concentrations (red triangles); and modelled organic aerosol (OA) mass concentrations vs. BC mass concentrations (green crosses). All modelled values are for 1-14 April 2015. (b) MAC values from Polar 6 flights and Alert observatory (1-14 April) plotted against measured refractory black carbon ( $\mathrm{rBC}$ ) mass concentrations (black dots); dust mass concentrations (red crosses) estimated from particle size distributions onboard the Polar 6 plotted against $\mathrm{rBC}$ mass concentrations; and MAC values associated with Polar 6 measurements only are identified (red circles). In (b), the black line is a power law fit to the black points. Power law fits were chosen since, based on the linear fit between absorption and rBC (Fig. 5), the expectation is that MAC will vary inversely with the $\mathrm{BC}$ mass concentration. The confidence level in the negative slopes is greater than $99 \%$.

particles, estimated from the Polar 6 size distributions, assuming a density of $2 \mathrm{~g} \mathrm{~cm}^{-3}$, are present across all $\mathrm{rBC}$ concentrations. We cannot distinguish whether the composition of these coarse particles is dust or sea salt, but, in accordance with the model, the observations suggest that dust may be a factor in the increasing MAC value at lower BC concentrations. Of course, factors that might enhance absorption by $\mathrm{BC}$ cannot be ruled out; for example, a relative increase in the coating thickness surrounding smaller $\mathrm{BC}$ cores at lower $\mathrm{BC}$ mass concentrations might contribute to an increased enhancement factor (Fig. 9). We add that the absolute absorption values at lower BC are small, and there is substantial uncertainty associated with the large amount of absorption data from the Polar 6 that lie below the detection limit. Despite the significance of the intercept for the Polar 6 plus Alert (114 April) data (Fig. 5), it is an extrapolation based on the assumption that the absorption data below detection limits follow the same linear fit.

At higher $\mathrm{BC}$ concentrations, the MAC versus $\mathrm{BC}$ curves in Fig. 8 approach the MAC values determined from Fig. 5 for the observations $\left(18.4 \mathrm{~m}^{2} \mathrm{~g}^{-1}\right)$ and from Fig. 6 for the model $\left(8.8\right.$ to $\left.14.0 \mathrm{~m}^{2} \mathrm{~g}^{-1}\right)$. Reasons for the higher observation-based MACs, based on the regression in Fig. 5, are unclear. There is no indication from the blue vs. green slopes (Fig. 2) to suggest that brown carbon is a significant factor for the Alert and Eureka data. Based on Figs. 5-8, we estimate that dust may have contributed to the absorption 


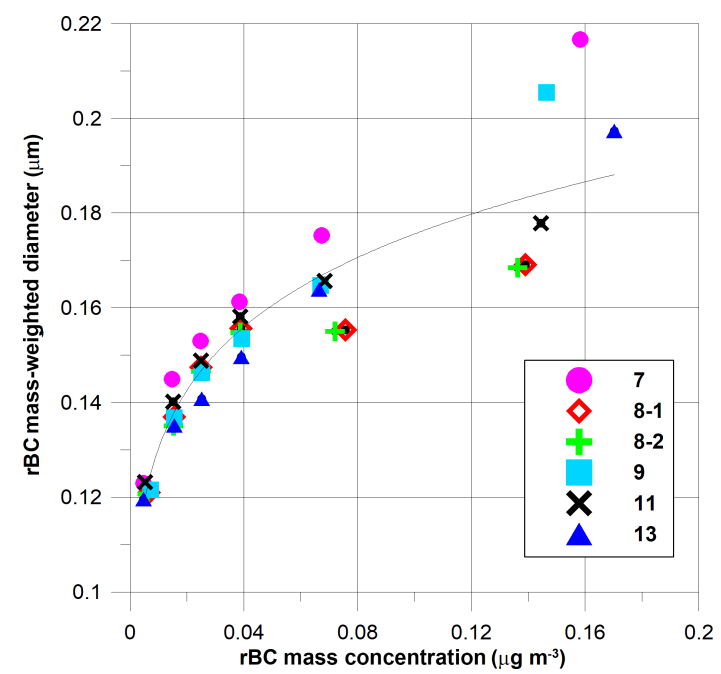

Figure 9. Mean mass-weighted diameters of rBC measurements vs. rBC mass concentrations, assuming spherical $\mathrm{rBC}$ components. Points are averages for mass concentration intervals of $0-0.01$, $0.01-0.02,0.02-0.03,0.03-0.05,0.05-0.1$ and 0.1 to the maximum observed. The power law fit $\left(y=0.237\left[x^{0.129}\right]\right)$ is through all points, with an $R^{2}$ of 0.89 and confidence level of better than $99 \%$. The power law is appropriate based on the relationship between the diameter and mass of a sphere, which includes the diameter going to zero as the mass goes to zero.

by roughly $0.15 \mathrm{Mm}^{-1}$. This estimate is significant, but not nearly sufficient, to explain the differences in observed and modelled MACs. We consider the following three additional possibilities for the higher MAC:

1. The higher MAC is reasonable. This is suggested by the recent observations in smoke plumes and in background particles over continental USA (Mason et al., 2018) and by Wu et al. (2016), whose modelling of soot aggregates shows that absorption by heavily coated soot can be about $60 \%$ higher than uncoated soot. Another factor suggesting that the higher MAC is reasonable is the close agreement between the present $\sigma_{\text {ap }}$ and SSA for Alert with the April summary of Schmeisser et al. (2018) for Alert; the $\sigma_{\text {ap }}$ are 0.50 and $0.45 \mathrm{Mm}^{-1}$ for the present Alert analysis and for Schmeisser et al. (2018), respectively, and the SSAs are 0.95 and 0.95 , respectively.

2. The higher observed MAC results from the overestimation of absorption by the filter-based measurements, as suggested by a number of observations. Lack et al. (2008) and Cappa et al. (2008a, b) found that $\sigma_{\text {abs }}$ measured with a PSAP ranged from 1.3 to over 2 times higher than $\sigma_{\text {abs }}$ measured with a photoacoustic technique for organic mass (OM) concentrations above $2.5 \mu \mathrm{g} \mathrm{m}^{-3}$, and the ratio of $\mathrm{OM}$ to the light-absorbing component of the carbonaceous components exceeded about 15 . To explain the absence of a similar effect on their results by ammonium sulfate particles, they suggested that the liquid nature of nonabsorbing $\mathrm{OM}$ enhanced multiple scattering across the filter, further increasing absorption by particles on the filter. For the present measurements of $\mathrm{rBC}$ and $\mathrm{OM}$ (see Figs. 10 and 15 ), the ratio of $\mathrm{OM}$ to $\mathrm{rBC}$ (the only significant absorbing carbon) is estimated to be between 15 and 20, consistent with a strong impact of OM on our results. However, Lack et al. (2008) and Cappa et al. (2008a, b) found that, for relatively low (OM), the PSAP-based $\sigma_{\text {abs }}$ was only $12 \%$ higher than the photoacoustic-based $\sigma_{\text {abs. }}$ At $1 \mu \mathrm{g} \mathrm{m}^{-3}$ or less (Fig. 15), our flight OM concentrations fall well into the low OM concentration range of Cappa et al. (2008a, b) and Lack et al. (2008). Also, consistent with the lowest level OM in Fig. 12, 3 years of $\mathrm{OM}$ measurements at Alert found $\mathrm{OM}$ was always less than $0.5 \mu \mathrm{g} \mathrm{m}^{-3}$ (Leaitch et al., 2018), suggesting that the average impact of this factor on our $\sigma_{\mathrm{abs}}$ may be in the area of $12 \%$. Considering the ambient temperatures $\left(-40\right.$ to $\left.-15^{\circ} \mathrm{C}\right)$, it is also possible that our nonabsorbing $\mathrm{OM}$ was in solid forms (e.g. Zobrist et al., 2008), which might render its behaviour on the filter more similar to ammonium sulfate. Sinha et al. (2017) studied the effect of volatile material (removed at $300^{\circ} \mathrm{C}$ ) on absorption by particles at two Arctic sites. On average, and for particles less than $1 \mu \mathrm{m}$, they found that the absorption given by the PSAP was reduced by $22 \%$ with the removal of volatile material, which suggests that the present correction based on $\sigma_{\mathrm{sp}}$ from the nephelometer may be insufficient.

3. The $\mathrm{BC}$ is underestimated here using $\mathrm{rBC}$. Sharma et al. (2017) found that filter-based thermo-optical measurements of elemental carbon (EC) were an average of 1.9 times higher than $\mathrm{rBC}$ measured at Alert. This result will explain the high MAC value of $18.4 \mathrm{~m}^{2} \mathrm{~g}^{-1}$, but there are many uncertainties associated with the measurement of $\mathrm{BC}$ by the many techniques, and the $\mathrm{rBC}$ measurement has been recommended for use (Bond et al., 2013). Schulz et al. (2019) estimate the deficiency in the Polar $6 \mathrm{rBC}$ mass concentrations due to sizing limitations at $7.5 \%$, but they did not consider potential bias with respect to particle size. Accounting for size limitations of the $\mathrm{rBC}$ measurement at Alert increased the BC estimate by $40 \%-50 \%$ during the spring measurement period (Sharma et al., 2017), although the resulting rBC was still a factor of 1.9 lower than the EC measurement.

If we assume that our observed $\sigma_{\text {abs }}$ are overestimated by $22 \%$ and our $\mathrm{rBC}$ are underestimated by $7.5 \%$, the MAC value is reduced from $18.4 \mathrm{~m}^{2} \mathrm{~g}^{-1}$ to about $13.4 \mathrm{~m}^{2} \mathrm{~g}^{-1}$, which is similar to the modelled MAC values based on the Allcore assumption but still about $50 \%$ higher than the more commonly accepted value of approximately $9 \mathrm{~m}^{2} \mathrm{~g}^{-1}$ that is similar to the modelled value for the more realistic Rshell assumption. However, because there are a number of potential 
factors influencing the measurements of both $\sigma_{\mathrm{abs}}$ and $\mathrm{BC}$, we cannot attribute one value with the necessary certainty. In the following, we consider the measured $\sigma_{\text {abs }}$, which give the MAC value of $18.4 \mathrm{~m}^{2} \mathrm{~g}^{-1}$, and values of $\sigma_{\mathrm{abs}}$ divided by a factor of 2 (i.e. $\sigma_{\mathrm{abs}} / 2$ ) that give a MAC value of $9.2 \mathrm{~m}^{2} \mathrm{~g}^{-1}$, which is close to the more common MAC and the modelled MAC, based on the Rshell assumption.

\subsection{BC, absorption, scattering and SSA vertical distributions}

We expand our data set of $\sigma_{\text {ap }}$ values by employing the linear regression between $\sigma_{\text {ap }}$ and $\mathrm{rBC}$, as shown in Fig. 5. This results in $956 \sigma_{\text {ap }}$ points instead of 220 , but because the linear relationship does not fully account for variations in individual points, we restrict the profiles of $\sigma_{\text {ap }}$ and SSAs to median values calculated over approximately equal $50 \mathrm{hPa}$ pressure intervals. Based on the linear fit, the uncertainty in the median $\sigma_{\text {ap }}$ is $6 \%$ at a $99 \%$ confidence level, but that excludes possible biases in either the measurement of $\sigma_{\text {ap }}$ or BC (as represented by $\mathrm{rBC}$ ) discussed in Sect. 3.2. The corresponding uncertainty in the median SSA is \pm 0.01 or less for the range of SSAs discussed here, again excluding possible biases. As discussed in Sect. 2.1, the profile data, including $\sigma_{\text {ap }}$ and $\sigma_{\text {ap }}$ (SSA is dimensionless), have been adjusted to a standard temperature and pressure $\left(20^{\circ} \mathrm{C}\right.$ and $\left.1013.25 \mathrm{hPa}\right)$ for the purposes of comparison. We note that in situ values of $\sigma_{\text {ap }}$ and $\sigma_{\text {ap }}$ are appropriate for calculating radiative effects.

Figure 10 shows vertical profiles of the rBC measurements of Schulz et al. (2018) and the modelled BC. Modelled BC for 1-14 April and rBC overlap well for pressures $>900 \mathrm{hPa}$. In the pressure region of $600-900 \mathrm{hPa}$, the modelled $\mathrm{BC}$ is about a factor of 2 lower than the Polar $6 \mathrm{rBC}$. Median $\mathrm{rBC}$ is $0.043 \mu \mathrm{g} \mathrm{m}^{-3}$ and median modelled BC for 1-14 April is $0.022 \mu \mathrm{g} \mathrm{m}^{-3}$. Using version 10.01 of GEOS-Chem (without TOMAS) and its adjoint, $\mathrm{Xu}$ et al. (2017) found that BC corresponding to these observations was dominated by sources from eastern and southern Asia. Xi et al. (2017) also found better agreement of modelled $\mathrm{BC}$ with these observations; although the same version of GEOS-Chem is used here, all biomass burning emissions were injected only within the boundary layer, potentially accounting for some of the lower modelled $\mathrm{BC}$ relative to $\mathrm{rBC}$. The relative increase in $\mathrm{rBC}$ in the $600-900 \mathrm{hPa}$ region is consistent with the mean profiles of McNaughton et al. (2011), and the median-observed $\mathrm{rBC}$ concentration in the $600-900 \mathrm{hPa}$ range is similar to the mode concentration of normally distributed values for "free tropospheric background haze" of $0.06 \mu \mathrm{g} \mathrm{m}^{-3}$ estimated by Brock et al. (2011). Also, the lower part of the profile concentration data $(<1 \mathrm{~km})$ is similar to the springtime lowlevel profile $\mathrm{BC}$ concentrations from $\mathrm{Ny}$-Ålesund measured by Ferrero et al. (2016). The present result is considerably lower than the medians of $0.1-0.5 \mu \mathrm{g} \mathrm{m}^{-3}$ measured in the Arctic in 1983 (Hansen and Rosen, 1984), 1986 (Hansen and Novakov, 1989) and 1992 (Hansen et al., 1997). A de-

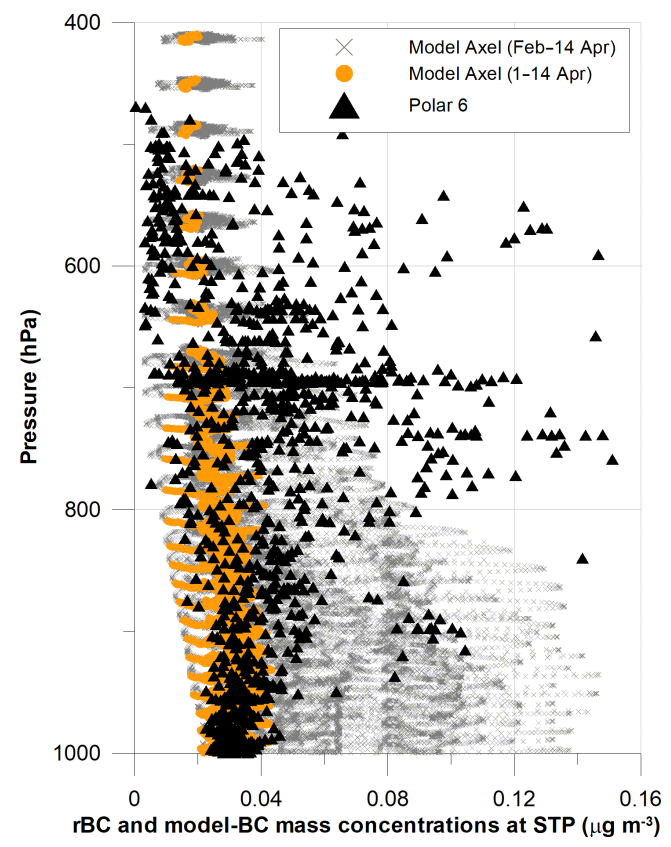

Figure 10. Vertical profile plot of BC mass concentrations from the model for the Axel grid (black crosses for February-14 April, inclusive; orange dots for 1-14 April only), and rBC mass concentrations from the Polar 6 observations (black triangles) plotted with pressure.

crease in BC at Alert, Nunavut, during the 1990s of more than $50 \%$ was associated with a reduction in Eurasian emissions (e.g. Sharma et al., 2019), and the present lower rBC concentrations near the surface may be connected to that reduction. Since east Asian emissions increased during the same time (e.g. van Donkelaar et al., 2008), it is difficult to assess the reason for the present lower concentrations in the 600-900 hPa range. It appears that the present observations mostly represent particles that spent a considerable length of time in the Arctic atmosphere.

Modelled profiles of $\sigma_{\text {ap }}$ for 1-14 April and both the Axel and NW Alert grids are shown in Fig. 11a-b for the Allcore and Rshell assumptions, respectively; major dust influence is removed, as in Fig. 6. The median values of the Polar 6 rBCbased $\sigma_{\text {ap }}$, covering the period of 7-13 April, inclusive, are also shown in Fig. 11, along with the hourly $\sigma_{\text {ap }}$ from Alert for 1-14 April. The black Polar 6 curves and Alert points are the measured values, and the red Polar 6 curves and Alert points indicate the results for the measured values divided by two or $\sigma_{\mathrm{ap}} / 2$. The median $\sigma_{\mathrm{ap}}$ from the Polar 6 agree reasonably with the corresponding Alert values. As expected, the modelled $\sigma_{\text {ap }}$ based on the Allcore assumption are overall higher than those based on the Rshell assumption. The simulated and observed $\sigma_{\text {ap }}$ exhibit opposite tendencies with pressure, except for pressures less than $600 \mathrm{hPa}$, where the model and Polar 6 both suggest an increasing tendency of $\sigma_{\text {ap }}$ with decreasing pressure, consistent with Samset et al. 


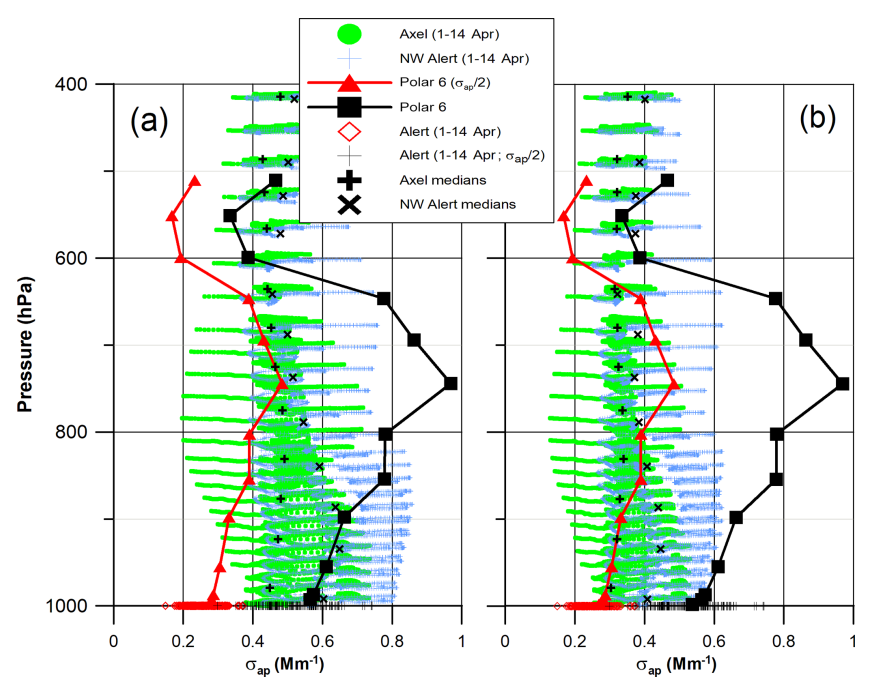

Figure 11. Vertical profile plots of $\sigma_{\text {ap }}$ with atmospheric pressure showing median values based on Polar 6 observations (black points). Red points represent the Polar $6 \sigma_{\mathrm{ap}} / 2$. Data from the Alert observatory for 1-14 April are shown for $\sigma_{\text {ap }}$ (black squares) and $\sigma_{\text {ap }} / 2$ (red squares). The model results are for 1-14 April, with the green dots representing the Axel grid and blue crosses representing the NW Alert grid. (a) Model results for the Allcore assumption and (b) model results for the Rshell assumption.

(2013). Near the surface, the Allcore simulations are closer to the observed $\sigma_{\text {ap }}$ and the Rshell simulations are closer to the $\sigma_{\mathrm{ap}} / 2$. Between 800 and $600 \mathrm{hPa}$, the modelled $\sigma_{\mathrm{ap}}$, for both assumptions, overlap best with the observed $\sigma_{\mathrm{ap}} / 2$.

Vertical profiles of SSAs are shown in Fig. 12. The modelled results are for February, March and 1-14 April 2015, with the upper $(\mathrm{a}-\mathrm{c})$ and lower panels $(\mathrm{d}-\mathrm{f})$ representing the Allcore and Rshell assumptions, respectively. Median values of the Alert SSAs, calculated from the measured $\sigma_{\mathrm{sp}}$ and $\sigma_{\mathrm{ap}}$, are shown for the corresponding model time period. The Polar 6 SSAs overlap well with the corresponding Alert SSAs for 1-14 April. The 1-14 April Alert SSAs, based on the higher MACs, are the same as those reported by Schmeisser et al. (2017) for Alert in April. The Alert SSAs increase from February to April, which suggests a combination of the near-surface air cleansing itself of BC faster than the air in the lower troposphere during the high Arctic spring-to-summer transition and long-range transport aloft maintaining its influence longer than transport near the surface. Near the surface $(>900 \mathrm{hPa})$, the modelled SSAs are lower than the Alert and Polar 6 results, in contrast to the modelled near-surface $\sigma_{\text {ap }}$ (Fig. 11). This difference is due to the modelled $\sigma_{\mathrm{sp}}$ being overall lower than the observed $\sigma_{\mathrm{sp}}$, as discussed below in connection with Fig. 13. In Fig. 12, the modelled and observation-based SSAs have opposite tendencies from the surface to about $600 \mathrm{hPa}$. In the $700-800 \mathrm{hPa}$ region, there is good agreement between the modelled SSAs for the Rshell mixing state and the observation-based SSAs for $\sigma_{\mathrm{ap}} / 2$. However, given that the modelled and measured $\sigma_{\mathrm{sp}}$ are in reasonable agreement in that region (Fig. 13), the SSA agreement seems inconsistent with the underestimation by the model of BC in that pressure region (Fig. 10). The Polar 6 near-surface $(>950 \mathrm{hPa})$ and Alert SSAs for early April range between 0.94 and 0.98 , roughly consistent with the boundary layer SSA estimates of $0.97( \pm 0.02)$ by Brock et al. (2011) and 0.95-0.96 by McNaughton et al. (2011). In the region of $600-900 \mathrm{hPa}$, the Polar 6 SSAs, based on $\sigma_{\mathrm{ap}} / 2$, range between 0.94 and 0.96 , which is also consistent with McNaughton et al. (2011) in this region and the free tropospheric background haze estimate of Brock et al. (2011). However, the Polar 6 SSAs, based on $\sigma_{\mathrm{ap}}$, range between 0.88 and 0.92 for the $600-900 \mathrm{hPa}$ region, indicating substantially more absorption relative to scattering in this altitude range than found by Brock et al. (2011) and McNaughton et al. (2011). As mentioned above, the ejection of biomass burning particles only into the boundary layer at the source may contribute to the higher modelled SSAs in the $600-900 \mathrm{hPa}$ layer.

Modelled $\sigma_{\mathrm{sp}}$ for the 1-14 April period and observed $\sigma_{\mathrm{sp}}$ are shown in Fig. 13a; only the model results for the Axel grid and Rshell assumption are shown, as those for the NW Alert grid are similar. The modelled and observed $\sigma_{\mathrm{sp}}$ are most similar in the $600-900 \mathrm{hPa}$ region, and therefore the differences between modelled and observation-based SSAs (Fig. 12) in this pressure region are primarily the result of the variations in $\sigma_{\text {ap }}$ (Fig. 11). Close to the surface $(>900 \mathrm{hPa})$, the $1-14$ April modelled $\sigma_{\mathrm{sp}}$ are lower than the Polar $6 \sigma_{\mathrm{sp}}$ and at the low end of the Alert $\sigma_{\mathrm{sp}}$, which contributes to the lower modelled SSAs relative to the observation-based SSAs in Fig. 10. Near the surface, the modelled $\sigma_{\mathrm{sp}}$ for February agree best with the observed $\sigma_{\mathrm{sp}}$, in part due to the higher submicron particle volumes simulated for February (Fig. 13b). The observed submicron volume concentrations are based on the UHSAS, and the modelled submicron volumes are calculated from the modelled mass concentrations of sulfate, organics and $\mathrm{BC}$ $\left(\mathrm{SO}_{4} / 1.8+\mathrm{Org} / 1.2+\mathrm{BC} / 1.8\right)$, where 1.8, 1.2 and 1.8 are the respective densities of these components. The modelled scattering efficiency (scattering coefficient divided by volume concentration) is significantly lower than the efficiency based on the observations. Near the surface ( $>900 \mathrm{hPa}$ ), the median of $\sigma_{\mathrm{sp}} /$ Volume from the observations is $12.1 \mu \mathrm{m}^{-1}$ (range of 7.2-26.3) compared with $7.3 \mu \mathrm{m}^{-1}$ (range of 5.610.3) from the model. For the pressure interval of 600$900 \mathrm{hPa}$, the median of $\sigma_{\mathrm{sp}} /$ Volume from the observations is $10.8 \mu \mathrm{m}^{-1}$ (range of 6.2-36.4) vs. $7.3 \mu \mathrm{m}^{-1}$ (range of 5.612.2) from the model. Model underestimation of submicron particle sizes may contribute to the lower modelled volume scattering efficiencies. In Fig. 14, the modelled particle size distributions for the Axel grid, for the 1-14 April period and averaged over the indicated pressure intervals are compared with measured distributions from the two flights (11 and 13 April) conducted in that grid. The modelled distribu- 

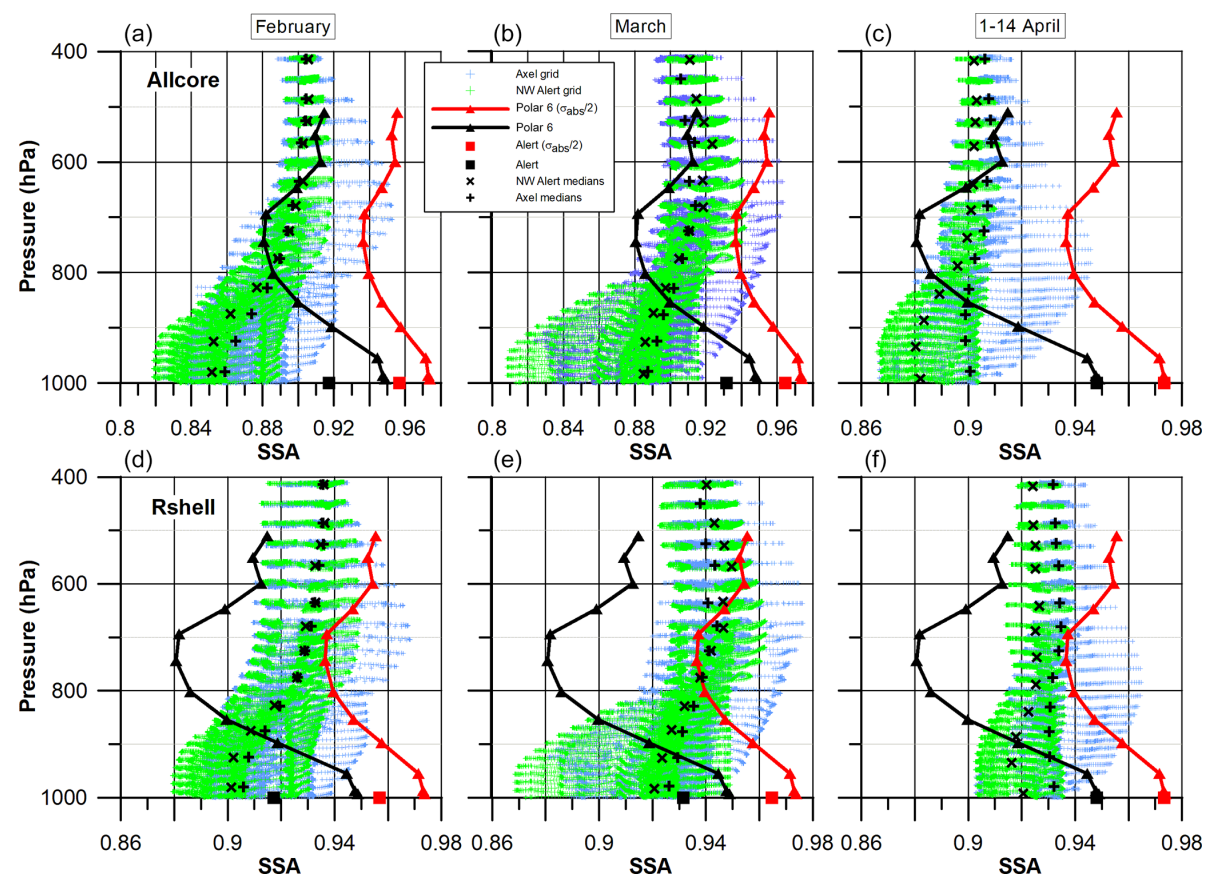

Figure 12. Vertical profile plot of SSAs with atmospheric pressure showing modelled results for February (a), March (b) and 1-14 April (c) based on the Allcore assumption. Results for February (d), March (e) and 1-14 April (f) based on the Rshell assumption. Median values of SSAs from the Polar 6 observations and the Alert observatory are based on the measured absorption (black points) and the assumption of $\sigma_{\mathrm{ap}} / 2$ (red points).

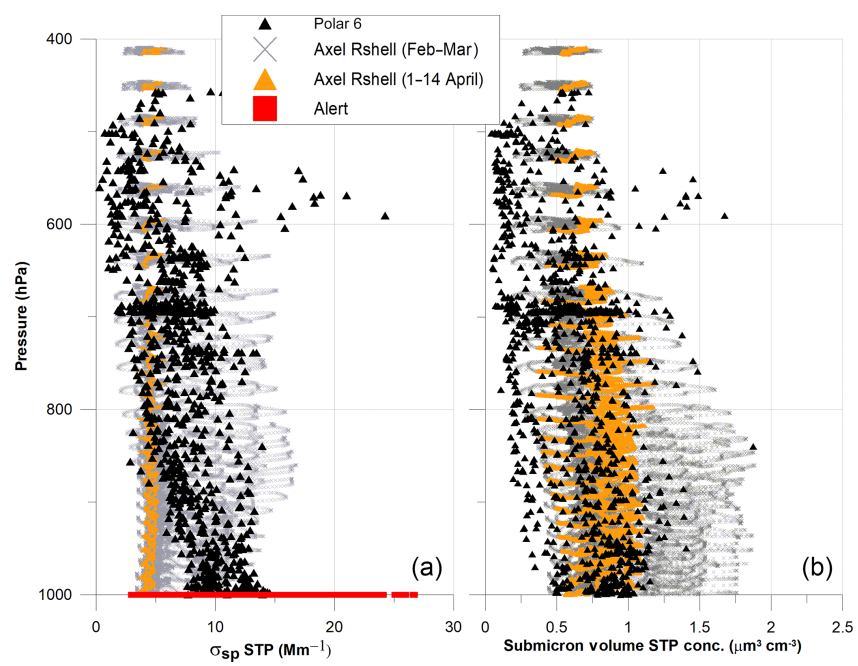

Figure 13. (a) Vertical profile plot of $\sigma_{\mathrm{sp}}$ from the model for the Axel grid (black crosses for February-14 April, inclusive; orange triangles for 1-14 April only) and $\sigma_{\mathrm{sp}}$ from the Polar 6 observations plotted with pressure. Also shown are the Alert observatory $\sigma_{\mathrm{sp}}$ for 1-14 April. (b) As in (a) but for submicron volume concentrations from the model simulations and Polar 6 observations. Volume concentrations from the Alert observatory are not shown. tions for the 800-900 and 900-1019 hPa intervals are shifted to slightly lower sizes relative to the average of the observations. The modelled distributions for $600-800 \mathrm{hPa}$ are a closer match to the measurements, and, for $400-600 \mathrm{hPa}$, the average of the modelled sizes is a reasonable match to the 11 April measurements but exceeds the 13 April observations. The overall pattern is generally consistent with the variation of the modelled $\sigma_{\mathrm{sp}}$ for the Axel grid and 1-14 April period, relative to the observed $\sigma_{\text {sp }}$, shown in Fig. 12a. In addition, the lower modelled volume scattering efficiencies may result from underestimation of the observed volumes that are based on the UHSAS.

The vertical distribution of the median concentrations of organic mass (OM) and sulfate mass (from Willis et al., 2018) are shown in Fig. 15 along with modelled organic and sulfate mass concentrations for the Axel grid; results for the NW Alert grid are not appreciably different. The increase in $\mathrm{rBC}$ from the surface to about $650 \mathrm{hPa}$ (Fig. 10) is paralleled by the increase in $\mathrm{OM}$ and its increase relative to sulfate. In Fig. 15, modelled OM near the surface ( $>900 \mathrm{hPa}$ ) is relatively close to the observed $\mathrm{OM}$, but above that the observed $\mathrm{OM}$ is higher by as much as a factor of 2 near $750 \mathrm{hPa}$. Near the surface, sulfate is underestimated by the model, which contributes to the model's lower volume and $\sigma_{\mathrm{sp}}$ (Fig. 13) and, hence, SSAs near the surface (Fig. 12). 


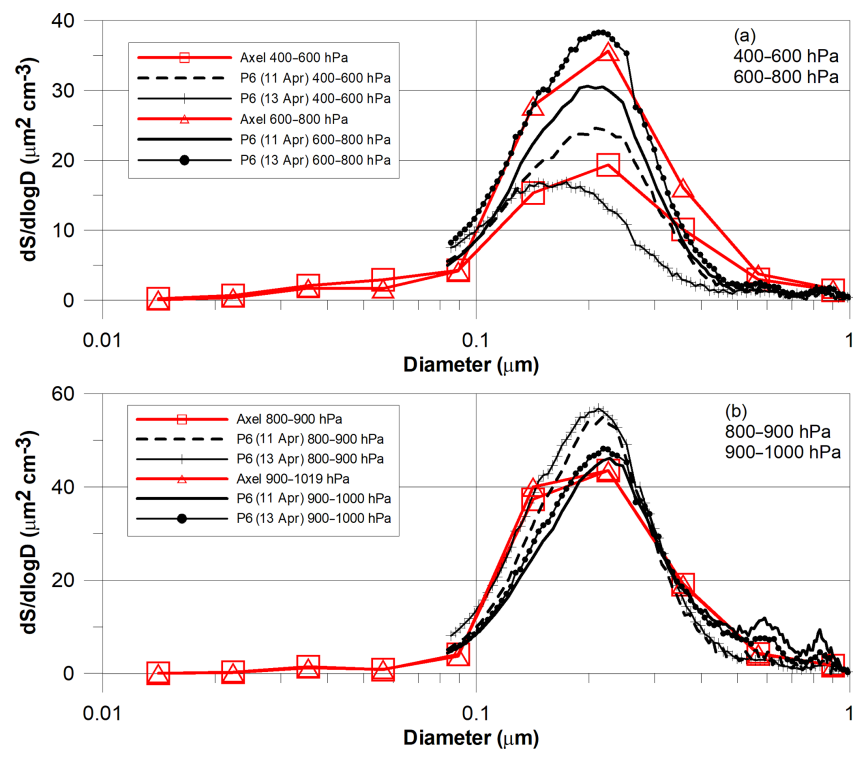

Figure 14. Comparison of modelled size distributions for the Axel grid and period of 1-14 April with the measured distributions from the Polar 6 (P6) flights on 11 and 13 April. All distributions are averaged for the indicated pressure intervals. (a) Modelled and measured distributions for pressure intervals of 400-600 and 600$800 \mathrm{hPa}$. (b) Modelled and measured distributions for pressure intervals of 800-900 and 900-1000 hPa.

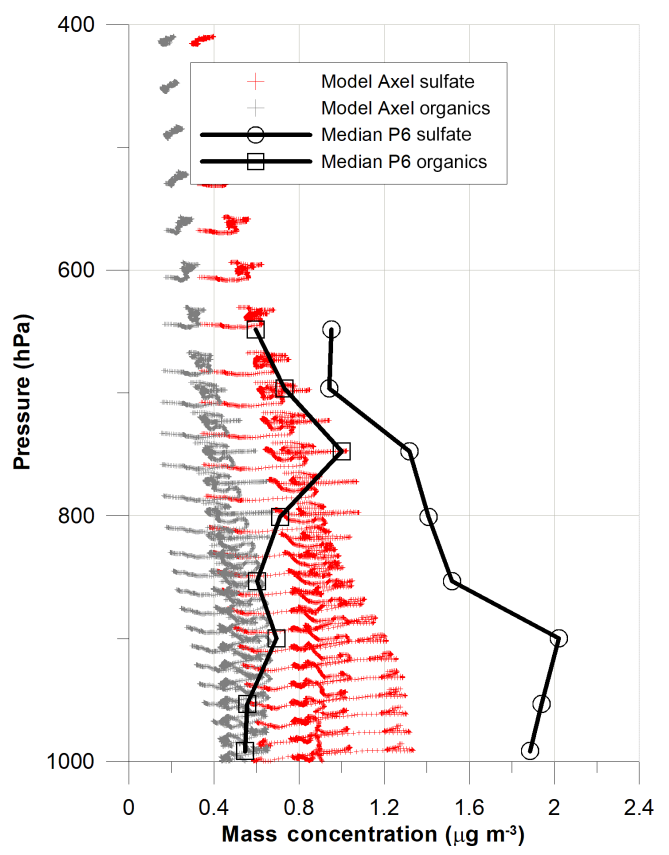

Figure 15. Vertical profile plot of mass concentrations of sulfate and of organics with pressure from the model for the Axel grid for 1-14 April (red crosses are sulfate and grey crosses are organics) and median values of the Polar 6 sulfate (open circles) and organic (open squares) mass concentrations.

\section{Discussion}

Models tend to underestimate Arctic BC (Bond et al., 2013; Eckhardt et al., 2015) and sulfate (Eckhardt et al., 2015). Emissions are an important aspect of such comparisons, and a recent study, using the European Centre Hamburg Model (ECHAM) model, showed that improved emissions inventories increase the annual BC burden over the Arctic by up to $30 \%$ (Schacht et al., 2019). The vertical distributions in Figs. 10 and 15 suggest that the BC emissions are coupled with other carbonaceous emissions to produce OM. In this case, the tendency of $\mathrm{rBC}-\mathrm{OM}$ is to increase with altitude, from approximately $5.8 \%$ near the surface to $7.3 \%$ at $650 \mathrm{hPa} ; 5.8 \%$ is equivalent to the slope of the modelled result in Fig. 7d. Variations in source emissions and secondary organic aerosol formation will explain some of the increase in $\mathrm{rBC}-\mathrm{OM}$ throughout this altitude range, but precipitation scavenging preferentially removing more organic material than $\mathrm{BC}$ is also a possibility. In the high Arctic, the number fractions of particles larger than $100 \mathrm{~nm}$ that contain detectable rBC are $<30 \%$ (e.g. Sharma et al., 2017; Kodros et al., 2018; references therein), which means there is significant potential for nucleation scavenging to separate $\mathrm{OM}$ (and sulfate) from BC as part of the precipitation process. As discussed by Targino et al. (2006) and Andrews et al. (2011), this may contribute to the general reduction in SSAs at lower $\sigma_{\mathrm{sp}}$.

The microphysics of the $\mathrm{rBC}$ components also supports the importance of wet deposition to the present observations. Schulz et al. (2019) showed that the mass mean diameter of the $\mathrm{rBC}$ components decreases with decreasing pressure from the surface, with an increase in the number of $\mathrm{rBC}$ containing particles explaining the higher $\mathrm{rBC}$ mass concentrations aloft. Wet deposition by convective clouds near the source regions will lead to smaller $\mathrm{BC}$ components of particles aloft, if the larger-sized $\mathrm{BC}$ components are scavenged, on average, more than smaller $\mathrm{BC}$ components nearer the emissions sources. The stronger emissions from more distant and southerly regions reaching higher altitudes (Stohl, 2006; $\mathrm{Xu}$ et al., 2017) could explain the general increase in $\mathrm{rBC}$ number concentrations with altitude. An important role for particle microphysics, and in particular in the representation of $\mathrm{BC}$ microphysics, in the modelling of $\mathrm{BC}$ transport to the Arctic is indicated. Despite the detailed microphysical model used here, the simulated $\mathrm{BC}$ vertical profiles suggest that the model transports more $\mathrm{BC}$ close to the surface. Excessive convective wet deposition that removes BC aloft (e.g. Mahmood et al., 2016), or redistributes it to the near-surface region, and the present modelled ejection of biomass burning particles only into the boundary layer are two potential reasons for the lower modelled $\mathrm{BC}$ in this case. These results are consistent with Matsui et al. (2018), who point out that for models to properly simulate $\mathrm{BC}$ and its radiative impact on the Arctic atmosphere, they must have good representations of the microphysics and scavenging aspects of $\mathrm{BC}$ and 
other components of the aerosol. The results of Targino et al. (2005) and Andrews et al. (2011), suggesting lower SSAs associated with lower $\sigma_{\mathrm{sp}}$, and the present results are examples showing that wet scavenging may enhance the relative absorption by the Arctic aerosol. In addition, contributions from smaller amounts of dust at the lower BC in this case (Fig. 8) may also factor in the lower SSAs at lower $\sigma_{\text {sp }}$.

Many studies have shown that BC may be of great importance to Arctic warming (e.g. Bond et al., 2013), and models compare better with ground-based observations in the Arctic than aloft (e.g. Eckhardt et al., 2015; present results). As discussed by Matsui et al. (2018) and indicated from the present work, the representation of particle microphysics, including $\mathrm{BC}$ microphysics and scavenging of $\mathrm{BC}$ relative to all particles, is critical. There remains a need for focussed airborne studies conducting high-quality and comprehensive measurements of BC microphysics and optical properties in the Arctic. Also, more knowledge of the BC mass absorption coefficient across the particle size spectrum is necessary if $\mathrm{BC}$ and its effects on absorption are to be properly assessed.

\section{Conclusions}

Relationships among vertically distributed aerosol optical properties $\left(\sigma_{\mathrm{abs}}, \sigma_{\mathrm{sp}}\right.$ and SSAs), microphysics and particle chemistry were examined for a region of the Canadian archipelago between 79.9 and $83.4^{\circ} \mathrm{N}$ from near the surface to $500 \mathrm{hPa}$. The airborne data were collected during April 2015 and combined with ground-based observations from the observatory at Alert, Nunavut, and simulations from the GEOS-Chem-TOMAS model (Kodros et al., 2018) in an effort to increase our knowledge of the effects of $\mathrm{BC}$ on absorption. The results were constrained for $\sigma_{\mathrm{sp}}$ less than $15 \mathrm{Mm}^{-1}$, which represent $98 \%$ of the observed $\sigma_{\mathrm{sp}}$, or the longer-lived Arctic haze, in this case.

Large uncertainties in estimating $\sigma_{\mathrm{ap}}$ and SSAs are associated with this combined data set. Based on observations from the Polar 6 and Alert observatory, the average mass absorption coefficient (MAC) for BC of $18.4 \mathrm{~m}^{2} \mathrm{~g}^{-1}$ was much higher than the averaged modelled values of 13.6 and $9.1 \mathrm{~m}^{2} \mathrm{~g}^{-1}$ (similar to some previous Arctic measurements), representing different internal mixing assumptions discussed by Kodros et al. (2018). The higher MAC value may be due to a number of factors, including underestimation of $\mathrm{BC}$, the presence of small amounts of dust, morphological arrangements of $\mathrm{BC}$ components within particles that are inconsistent with the often used core-shell concept and an overestimation of $\sigma_{\text {ap }}$ by our observations. Due to the uncertainties, we compared $\sigma_{\mathrm{ap}}$ and SSAs against the modelled results, using the values as measured and using values based on $\sigma_{\mathrm{ap}} / 2$, to provide a range consistent with the modelled MAC values.

Measured $\sigma_{\mathrm{abs}}, \mathrm{rBC}$ and organic material in the particles all increased by close to a factor of 2, going from the surface to $750 \mathrm{hPa}$. Modelled $\mathrm{BC}$, organics and $\sigma_{\text {ap }}$ did not reflect the higher measured values in the $600-900 \mathrm{hPa}$ region. The main sources of the differences between modelled and observed optical properties are the differences between the simulated and observed vertical distributions of $\mathrm{rBC}$, organics and sulfate. As discussed, this highlights not only the importance of improving model emissions, deposition and transport processes but also microphysical details.

Assuming absorption overestimation, the SSAs based on the Polar 6 measurements ranged between 0.94 and 0.98 , consistent with the results of Brock et al. (2011) and McNaughton et al. (2011). Assuming the measured MAC is reasonable, the SSAs ranged between 0.88 and 0.94 , consistent with Schmeisser et al. (2017). The lower $\sigma_{\mathrm{sp}}\left(<15 \mathrm{Mm}^{-1}\right)$ constraint has been shown to yield lower SSA values on average (Targino et al., 2005; Andrews et al., 2011; this work). The relatively high frequency of occurrence of $\sigma_{\mathrm{sp}}<$ $15 \mathrm{Mm}^{-1}$ in this region of the Arctic during April makes it important to understand the size distributions and morphology of $\mathrm{BC}$ in particles at these lower $\sigma_{\mathrm{sp}}$, the impact of smaller dust concentrations, and to be able to simulate sizedistributed wet scavenging of $\mathrm{BC}$.

This work typifies the large uncertainty that exists in our knowledge of the contribution from $\mathrm{BC}$ to direct warming of the Arctic atmosphere. It suggests a lower level of confidence in assessing direct absorption by $\mathrm{BC}$ and the need for more detailed efforts if the impact of $\mathrm{BC}$ on Arctic climate is to be properly established. Those efforts include improved measurements of BC and absorption and more vertical profiles of aerosol chemistry, microphysics and optical properties.

Code availability. The GEOS-Chem model is available for download at https://github.com/geoschem/geos-chem (GEOS-Chem, 2020).

Data availability. NETCARE data presented in this publication are publicly available at http://crd-data-donnees-rdc.ec.gc.ca/CCCMA/ products/NETCARE/ (Abbatt et al., 2019).

Author contributions. JPDA, WRL and AH conceived and designed the measurements. WRL, JKK and JRP analyzed the measurements and model simulations and wrote the paper with critical feedback from ES, JAO and KvS. MDW, HS, EA, HB, JB, PH, SH, FK, JAO, SS, MS, AKB, JPDA and WRL contributed to collection and quality control of the data. The paper was critically reviewed by all authors.

Competing interests. The authors declare that they have no conflict of interest.

Acknowledgements. We gratefully acknowledge Kenn Borek Air Ltd., in particular our pilots and crew Garry Murtsell, Neil Tra- 
verse and Doug Mackenzie, for their support of our measurements. Logistical and technical support before and during the campaign was provided by a number of contributors, in particular by Desiree Toom (ECCC), Andrew Elford (ECCC), Dan Veber (ECCC), Julia Binder (AWI), Lukas Kandora (AWI), Jens Herrmann (AWI) and Manuel Sellmann (AWI). Extensive logistical and technical support was also provided by Andrew Platt (ECCC), Mike Harwood (ECCC) and Martin Gerhmann (AWI). We are grateful to CFS Alert and Eureka Weather Station for supporting the measurements presented in this work. We thank the reviewers of this paper for their many helpful comments.

Financial support. NETCARE was funded by the Natural Sciences and Engineering Research Council (NSERC) of Canada under its Climate Change and Atmospheric Research program, with additional financial and in-kind support from Environment and Climate Change Canada (ECCC), Fisheries and Oceans Canada, the Alfred Wegener Institute, the Major Research Project Management Fund at the University of Toronto, and the Deutsche Forschungsgemeinschaft (DFG - German Research Foundation; grant no. 268020496) TRR 172, within the Transregional Collaborative Research Center, "ArctiC Amplification: Climate Relevant Atmospheric and SurfaCe Processes, and Feedback Mechanisms (AC) ${ }^{3}$ ". Colorado State University researchers were supported by the US Department of Energy's Atmospheric System Research (an Office of Science and Office of Biological and Environmental Research program; grant no. DE-SC0011780), the US National Science Foundation under the Atmospheric Chemistry program (grant no. AGS-1559607), and by the US National Oceanic and Atmospheric Administration (an Office of Science and Office of Atmospheric Chemistry, Carbon Cycle, and Climate program; grant no. NA17OAR430001).

Review statement. This paper was edited by Lynn M. Russell and reviewed by three anonymous referees.

\section{References}

Abbatt, J. P. D., Leaitch, W. R., Aliabadi, A. A., Bertram, A. K., Blanchet, J.-P., Boivin-Rioux, A., Bozem, H., Burkart, J., Chang, R. Y. W., Charette, J., Chaubey, J. P., Christensen, R. J., Cirisan, A., Collins, D. B., Croft, B., Dionne, J., Evans, G. J., Fletcher, C. G., Galí, M., Ghahremaninezhad, R., Girard, E., Gong, W., Gosselin, M., Gourdal, M., Hanna, S. J., Hayashida, H., Herber, A. B., Hesaraki, S., Hoor, P., Huang, L., Hussherr, R., Irish, V. E., Keita, S. A., Kodros, J. K., Köllner, F., Kolonjari, F., Kunkel, D., Ladino, L. A., Law, K., Levasseur, M., Libois, Q., Liggio, J., Lizotte, M., Macdonald, K. M., Mahmood, R., Martin, R. V., Mason, R. H., Miller, L. A., Moravek, A., Mortenson, E., Mungall, E. L., Murphy, J. G., Namazi, M., Norman, A.-L., O’Neill, N. T., Pierce, J. R., Russell, L. M., Schneider, J., Schulz, H., Sharma, S., Si, M., Staebler, R. M., Steiner, N. S., Thomas, J. L., von Salzen, K., Wentzell, J. J. B., Willis, M. D., Wentworth, G. R., Xu, J.-W., and Yakobi-Hancock, J. D.: Overview paper: New insights into aerosol and climate in the Arctic, Atmos. Chem. Phys., 19, 2527-2560, https://doi.org/10.5194/acp-192527-2019, 2019 (data available at: http://crd-data-donnees-rdc.
ec.gc.ca/CCCMA/products/NETCARE/, last access: 7 September 2020).

Adams, P. J. and Seinfeld, J. H.: Predicting global aerosol size distributions in general circulation models, J. Geophys. Res., 107, 4370, https://doi.org/10.1029/2001JD001010, 2002.

Alvarado, M. J., Lonsdale, C. R., Macintyre, H. L., Bian, H., Chin, M., Ridley, D. A., Heald, C. L., Thornhill, K. L., Anderson, B. E., Cubison, M. J., Jimenez, J. L., Kondo, Y., Sahu, L. K., Dibb, J. E., and Wang, C.: Evaluating model parameterizations of submicron aerosol scattering and absorption with in situ data from ARCTAS 2008, Atmos. Chem. Phys., 16, 9435-9455, https://doi.org/10.5194/acp-16-9435-2016, 2016.

Anderson, T. L. and Ogren, J. A.: Determining aerosol radiative properties using TSI 3563 integrating nephelometer, Aerosol Sci. Tech., 29, 57-69, 1998.

Andrews, E., Ogren, J. A., Bonasoni, P., Marinoni, A., Cuevas, E., Rodriguez, S., Sun, J. Y., Jaffe, D., Fischer, E., Baltensperger, U., Weingartner, E., Collaud Coen, M., Sharma, S., Macdonald, A., Leaitch, W. R., Lin, N.-H., Laj, P., Stamenov, J., Kalapov, I., Jefferson, A., Sheridan, P.: Climatology of aerosol radiative properties in the free troposphere, Atmos. Res., 102, 365-393, https://doi.org/10.1016/j.atmosres.2011.08.017, 2011.

Aryal, R. P., Voss, K. J., Terman, P. A., Keene, W. C., Moody, J. L., Welton, E. J., and Holben, B. N.: Comparison of surface and column measurements of aerosol scattering properties over the western North Atlantic Ocean at Bermuda, Atmos. Chem. Phys., 14, 7617-7629, https://doi.org/10.5194/acp14-7617-2014, 2014.

Barrie, L. A.: Arctic air pollution: An overview of current knowledge, Atmos. Environ., 20, 643-663, https://doi.org/10.1016/0004-6981(86)90180-0, 1986.

Barrie, L. A. and Hoff, R. M.: Five years of air chemistry observations in the Canadian Arctic, Atmos. Environ., 19, 1995-2010, 1985.

Bigg, E. K.: Comparison of aerosol at four baseline monitoring stations, J. Appl. Meteorol., 19, 521-523, 1980.

Blanchet, J.-P. and List, R.: Estimation of optical properties of Arctic Haze using a numerical model, Atmos.-Ocean, 21, 444-464, 1987.

Bohren, C. F. and Huffman, D. R.: Absorption and scattering of light by small particles, Wiley Interscience, New York, USA, 1983.

Bond, T. C. and Bergstrom, R. W.: Light absorption by carbonaceous particles: an investigative review, Aerosol Sci. Tech., 40, 27-67, 2006.

Bond, T. C., Anderson, T. L., and Campbell, D.: Calibration and intercomparison of filter-based measurements of visible light $a b-$ sorption by aerosols, Aerosol Sci. Tech., 30, 582-600, 1999.

Bond, T. C., Doherty, S. J., Fahey, D. W., Forster, P. M., Berntsen, T., DeAngelo, B. J., Flanner, M. G., Ghan, S., Kärcher, B., Koch, D., Kinne, S., Kondo, Y., Quinn, P. K., Sarofim, M. C., Schultz, M. G., Schulz, M., Venkataraman, C., Zhang, H., Zhang, S., Bellouin, N., Guttikunda, S. K., Hopke, P. K., Jacobson, M. Z., Kaiser, J. W., Klimont, Z., Lohmann, U., Schwarz, J. P., Shindell, D., Storelvmo, T., Warren, S. G., and Zender, C. S.: Bounding the role of black carbon in the climate system: A scientific assessment, J. Geophys. Res.-Atmos., 118, 5380-5552, https://doi.org/10.1002/jgrd.50171, 2013.

Brock, C. A., Cozic, J., Bahreini, R., Froyd, K. D., Middlebrook, A. M., McComiskey, A., Brioude, J., Cooper, O. R., Stohl, A., 
Aikin, K. C., de Gouw, J. A., Fahey, D. W., Ferrare, R. A., Gao, R.-S., Gore, W., Holloway, J. S., Hübler, G., Jefferson, A., Lack, D. A., Lance, S., Moore, R. H., Murphy, D. M., Nenes, A., Novelli, P. C., Nowak, J. B., Ogren, J. A., Peischl, J., Pierce, R. B., Pilewskie, P., Quinn, P. K., Ryerson, T. B., Schmidt, K. S., Schwarz, J. P., Sodemann, H., Spackman, J. R., Stark, H., Thomson, D. S., Thornberry, T., Veres, P., Watts, L. A., Warneke, C., and Wollny, A. G.: Characteristics, sources, and transport of aerosols measured in spring 2008 during the aerosol, radiation, and cloud processes affecting Arctic Climate (ARCPAC) Project, Atmos. Chem. Phys., 11, 24232453, https://doi.org/10.5194/acp-11-2423-2011, 2011.

Clarke, A., McNaughton, C., Kapustin, V., Shinozuka, Y., Howell, S., Dibb, J., Zhou, J., Anderson, B., Brekhovskikh, V., Turner, H., and Pinkerton, M.: Biomass burning and pollution aerosol over North America: Organic components and their influence on spectral optical properties and humidification response, J. Geophys. Res., 112, D12S18, https://doi.org/10.1029/2006JD007777, 2007.

Croft, B., Pierce, J. R., Martin, R. V., Hoose, C., and Lohmann, U.: Uncertainty associated with convective wet removal of entrained aerosols in a global climate model, Atmos. Chem. Phys., 12, 10725-10748, https://doi.org/10.5194/acp-12-107252012, 2012.

Delene, D. and Ogren, J. A.: Variability of aerosol optical properties at Four North American Surface Monitoring Sites, J. Atmos. Sci., 59, 1135-1150, 2002.

Düsing, S., Wehner, B., Müller, T., Stöcker, A., and Wiedensohler, A.: The effect of rapid relative humidity changes on fast filterbased aerosol-particle light-absorption measurements: uncertainties and correction schemes, Atmos. Meas. Tech., 12, 58795895, https://doi.org/10.5194/amt-12-5879-2019, 2019.

Dymarska, M., Murray, B. J., Sun, L., Eastwood, M. L., Knopf, D. A., and Bertram, A. K.: Deposition ice nucleation on soot at temperatures relevant for the lower troposphere, J. Geophys. Res., 111, D04204, https://doi.org/10.1029/2005JD006627, 2006.

Eckhardt, S., Quennehen, B., Olivié, D. J. L., Berntsen, T. K., Cherian, R., Christensen, J. H., Collins, W., Crepinsek, S., Daskalakis, N., Flanner, M., Herber, A., Heyes, C., Hodnebrog, Ø., Huang, L., Kanakidou, M., Klimont, Z., Langner, J., Law, K. S., Lund, M. T., Mahmood, R., Massling, A., Myriokefalitakis, S., Nielsen, I. E., Nøjgaard, J. K., Quaas, J., Quinn, P. K., Raut, J.-C., Rumbold, S. T., Schulz, M., Sharma, S., Skeie, R. B., Skov, H., Uttal, T., von Salzen, K., and Stohl, A.: Current model capabilities for simulating black carbon and sulfate concentrations in the Arctic atmosphere: a multi-model evaluation using a comprehensive measurement data set, Atmos. Chem. Phys., 15, 9413-9433, https://doi.org/10.5194/acp-15-9413-2015, 2015.

Ferrero, L., Cappelletti, D., Busetto, M., Mazzola, M., Lupi, A., Lanconelli, C., Becagli, S., Traversi, R., Caiazzo, L., Giardi, F., Moroni, B., Crocchianti, S., Fierz, M., Močnik, G., Sangiorgi, G., Perrone, M. G., Maturilli, M., Vitale, V., Udisti, R., and Bolzacchini, E.: Vertical profiles of aerosol and black carbon in the Arctic: a seasonal phenomenology along 2 years (2011-2012) of field campaigns, Atmos. Chem. Phys., 16, 12601-12629, https://doi.org/10.5194/acp-16-12601-2016, 2016.

Fisher, J. A., Jacob, D. J., Wang, Q., Bahreini, R., Carouge, C. C., Cubison, M. J., Dibb, J. E., Diehl, T., Jimenez, J. L., Leibensperger, E. M., Lu, Z., Meinders, M. B. J.,
Pye, H. O. T., Quinn, P. K., Sharma, S., Streets, D. G., van Donkelaar, A., and Yantosca, R. M.: Sources, distribution, and acidity of sulfate-ammonium aerosol in the Arctic in winter-spring, Atmos. Environ., 45, 7301-7318, https://doi.org/10.1016/j.atmosenv.2011.08.030, 2011.

Flanner, M., Zender, C., Randerson, J., and Rasch, P.: Present-day climate forcing and response from black carbon in snow, J. Geophys. Res., 112, D11202, https://doi.org/10.1029/2006JD008003, 2007.

GEOS-Chem: GEOS-Chem model, available at: https://github.com/ geoschem/geos-chem, last access: 1 September 2020.

Gysel, M., Laborde, M., Olfert, J. S., Subramanian, R., and Gröhn, A. J.: Effective density of Aquadag and fullerene soot black carbon reference materials used for SP2 calibration, Atmos. Meas. Tech., 4, 2851-2858, https://doi.org/10.5194/amt-4-2851-2011, 2011.

Hallar, A. G., Petersen, R., Andrews, E., Michalsky, J., McCubbin, I. B., and Ogren, J. A.: Contributions of dust and biomass burning to aerosols at a Colorado mountain-top site, Atmos. Chem. Phys., 15, 13665-13679, https://doi.org/10.5194/acp-15-136652015, 2015.

Hansen, J. and Nazarenko, L.: Soot climate forcing via snow and ice albedos, P. Natl. Acad. Sci. USA, 101, 423-428, https://doi.org/10.1073/pnas.2237157100, 2004.

Hansen, A. D. A. and Novakov, T.: Aerosol black carbon measurements in the Arctic haze during AGASP-II, J. Atmos. Chem., 9, 347-361, 1989.

Hansen, A. D. A. and Rosen, H.: Vertical distribution of particulate carbon, sulfur, and bromine in the Arctic haze and comparison with ground-level measurements at Barrow, Alaska, Geophys. Res. Lett., 11, 381-384, 1984.

Hansen, A. D. A. and Rosen, H.: Horizontal inhomogeneities in the particulate carbon component of the Arctic haze, Atmos. Environ., 19, 2175-2180, 1985.

Hansen, A. D. A., Polissar, A. V., Schnell, R. C.: Airborne aerosol and black carbon measurements over the East Siberian Sea, spring 1992, Atmos. Res., 44, 153-166, 1997.

Heidam, N. Z., Wåhlin, P., and Christensen, J. H.: Tropospheric gases and aerosols in northeast Greenland, J. Atmos. Sci., 56, 261-278, 1999.

Heintzenberg, J.: Particle size distribution and optical properties-of Arctic haze, Tellus, 32, 251-260, 1980.

Hess, M., Koepke, P., and Schult, I.: Optical Properties of Aerosols and Clouds: The software package OPAC, B. Am. Meteorol. Soc., 79, 831-844, https://doi.org/10.1175/15200477(1998)079<0831:OPOAAC>2.0.CO;2, 1998.

Hirdman, D., Burkhart, J. F., Sodemann, H., Eckhardt, S., Jefferson, A., Quinn, P. K., Sharma, S., Ström, J., and Stohl, A.: Long-term trends of black carbon and sulphate aerosol in the Arctic: changes in atmospheric transport and source region emissions, Atmos. Chem. Phys., 10, 9351-9368, https://doi.org/10.5194/acp-109351-2010, 2010.

Holmgren, B., Shaw G. E., and Weller, G.: Turbidity in the Arctic atmosphere, AIDJEX Bull., 27, 135-148, 1974.

Jaeglé, L., Quinn, P. K., Bates, T. S., Alexander, B., and Lin, J.-T.: Global distribution of sea salt aerosols: new constraints from in situ and remote sensing observations, Atmos. Chem. Phys., 11, 3137-3157, https://doi.org/10.5194/acp-11-3137-2011, 2011. 
Janssens-Maenhout, G., Crippa, M., Guizzardi, D., Dentener, F., Muntean, M., Pouliot, G., Keating, T., Zhang, Q., Kurokawa, J., Wankmüller, R., Denier van der Gon, H., Kuenen, J. J. P., Klimont, Z., Frost, G., Darras, S., Koffi, B., and Li, M.: HTAP_v2.2: a mosaic of regional and global emission grid maps for 2008 and 2010 to study hemispheric transport of air pollution, Atmos. Chem. Phys., 15, 11411-11432, https://doi.org/10.5194/acp-15-11411-2015, 2015.

Kahnert, M.: On the discrepancy between modeled and measured Mass absorption cross sections of light Absorbing carbon Aerosols, Aerosol Sci. Tech., 44, 453-460, https://doi.org/10.1080/02786821003733834, 2010

Kim, J., Bauer, H., Dobovičnik, T., Hitzenberger, R., Lottin, D., Ferry, D., and Petzold, A.: Assessing optical properties and refractive index of combustion aerosol particles through combined experimental and modeling Studies, Aerosol Sci. Tech., 49, 340350, https://doi.org/10.1080/02786826.2015.1020996, 2015.

Klimont, Z., Kupiainen, K., Heyes, C., Purohit, P., Cofala, J., Rafaj, P., Borken-Kleefeld, J., and Schöpp, W.: Global anthropogenic emissions of particulate matter including black carbon, Atmos. Chem. Phys., 17, 8681-8723, https://doi.org/10.5194/acp-178681-2017, 2017.

Kodros, J. K., Hanna, S. J., Bertram, A. K., Leaitch, W. R., Schulz, H., Herber, A. B., Zanatta, M., Burkart, J., Willis, M. D., Abbatt, J. P. D., and Pierce, J. R.: Size-resolved mixing state of black carbon in the Canadian high Arctic and implications for simulated direct radiative effect, Atmos. Chem. Phys., 18, 11345-11361, https://doi.org/10.5194/acp-18-11345-2018, 2018.

Kopke, P., Hess, M., Schult, I., and Shettle, E. P.: Global aerosol data set, Max Planck Inst. für Meteorol., Hamburg, Germany, available at: http://hdl.handle.net/10068/256361 (last access: 31 August 2020), 1997.

Kopp, R. E. and Mauzerall, D. L.: Assessing the climatic benefits of black carbon mitigation, P. Natl. Acad. Sci. USA, 107, $11703-$ 11708, https://doi.org/10.1073/pnas.0909605107, 2010.

Laborde, M., Mertes, P., Zieger, P., Dommen, J., Baltensperger, U., and Gysel, M.: Sensitivity of the Single Particle Soot Photometer to different black carbon types, Atmos. Meas. Tech., 5, 10311043, https://doi.org/10.5194/amt-5-1031-2012, 2012.

Lack, D. A., Cappa, C. D., Covert, D. S., Baynard, T., Massoli, P., Sierau, B., Bates, T. S., Quinn, P. K., Lovejoy, E. R., and Ravishankara, A. R.: Bias in filter-based aerosol light absorption measurements due to organic aerosol loading: Evidence from ambient measurements, Aerosol Sci. Tech., 42, 1033-1041, 2008.

Law, K. S. and Stohl, A.: Arctic air pollution: origins and impacts, Science, 315, 1537-1540, 2007.

Leaitch, W. R., Hoff, R. M., and MacPherson, J. I.: Airborne and lidar measurements of aerosol and cloud particles in the troposphere over Alert Canada in April 1986, J. Atmos. Chem., 9, 187-211, 1989.

Leaitch, W. R., Sharma, S., Huang, L., Macdonald, A. M., ToomSauntry, D., Chivulescu, A. , von Salzen, K., Pierce, J. R., Shantz, N. C., Bertram, A., Schroder, J. , Norman, A.-L., and Chang, R. Y.-W.: Dimethyl sulphide control of the clean summertime Arctic aerosol and cloud, Elementa, 1, 000017, https://doi.org/10.12952/journal.elementa.000017, 2013.

Leaitch, W. R., Russell, L. M., Liu, J., Kolonjari, F., Toom, D., Huang, L., Sharma, S., Chivulescu, A., Veber, D., and Zhang, W.: Organic functional groups in the submicron aerosol at $82.5^{\circ} \mathrm{N}$, $62.5^{\circ} \mathrm{W}$ from 2012 to 2014, Atmos. Chem. Phys., 18, 3269 3287, https://doi.org/10.5194/acp-18-3269-2018, 2018.

Lee, Y. H. and Adams, P. J.: A fast and efficient version of the TwO-Moment Aerosol Sectional (TOMAS) global aerosol microphysics model, Aerosol Sci. Tech., 46, 678-689, https://doi.org/10.1080/02786826.2011.643259, 2012.

Lee, Y. H., Pierce, J. R., and Adams, P. J.: Representation of nucleation mode microphysics in a global aerosol model with sectional microphysics, Geosci. Model Dev., 6, 1221-1232, https://doi.org/10.5194/gmd-6-1221-2013, 2013.

Leighton, H.: Influence of the Arctic Haze on the solar radiation budget, Atmos. Environ., 17, 2065-2068, 1983.

Liu, F., Yon, J., Fuentes, A., Lobo, P., Smallwood, G. J., and Corbin, J. C.: Review of recent literature on the light absorption properties of black carbon: Refractive index, mass absorption cross section, and absorption function, Aerosol Sci. Tech., 54, 33-51, https://doi.org/10.1080/02786826.2019.1676878, 2020.

Mahmood, R., Salzen, K., Flanner, M., Sand, M., Langner, J., Wang, H., and Huang, L.: Seasonality of global and Arctic black carbon processes in the Arctic Monitoring and Assessment Programme models, J. Geophys. Res.-Atmos., 121, 7100-7116, 2016.

Markowicz, K. M., Ritter, C., Lisoka, J., Makuch, P., Stachlewska, S., Cappelletti, D., Mazzola, M., and Chilinski, M. T.: Vertical variability of aerosol single-scattering albedo and equivalent black carbon concentration based on in-situ and remote sensing techniques during the iAREA campaigns in Ny-Ålesund, Atmos. Environ., 164, 431-447, https://doi.org/10.1016/j.atmosenv.2017.06.014, 2017.

Mason, B., Wagner, N. L., Adler, G., Andrews, E., Brock, C. A., Gordon, T. D., Lack, D. A., Perring, A. E., Richardson, M. S., Schwarz, J. P., Shook, M. A., Thornhill, K. L., Ziembad, L. D., and Murphy, D. M.: An intercomparison of aerosol absorption measurements conducted during the SEAC4RS campaign, Aerosol Sci. Tech., 52, 1012-1027, https://doi.org/10.1080/02786826.2018.1500012, 2018.

Matsui, H., Hamilton, D. S., and Mahowald, N. M.: Black carbon radiative effects highly sensitive to emitted particle size when resolving mixing-state diversity, Nat. Commun., 9, 3446, https://doi.org/10.1038/s41467-018-05635-1, 2018.

McConnell, J. R., Edwards, E., Kok, G. L., Flanner, M. G., Zender, C. S., Saltzman, E. S., Banta, J. R., Pasteris, D. R., Carter, M. M., and Kahl, J. D.: 20th-century industrial black carbon emissions altered Arctic climate, Science, 317, 1381-1384, 2007.

McNaughton, C. S., Clarke, A. D., Freitag, S., Kapustin, V. N., Kondo, Y., Moteki, N., Sahu, L., Takegawa, N., Schwarz, J. P., Spackman, J. R., Watts, L., Diskin, G., Podolske, J., Holloway, J. S., Wisthaler, A., Mikoviny, T., de Gouw, J., Warneke, C., Jimenez, J., Cubison, M., Howell, S. G., Middlebrook, A., Bahreini, R., Anderson, B. E., Winstead, E., Thornhill, K. L., Lack, D., Cozic, J., and Brock, C. A.: Absorbing aerosol in the troposphere of the Western Arctic during the 2008 ARCTAS/ARCPAC airborne field campaigns, Atmos. Chem. Phys., 11, 7561-7582, https://doi.org/10.5194/acp-117561-2011, 2011.

Mitchell, M.: Visual range in the polar regions with particular reference to the Alaskan Arctic, J. Atmos. Terr. Phys., Special Supplement, 195-211, 1956.

Moteki, N. and Kondo, Y.: Effects of mixing state on black carbon measurements by laser-induced 
incandescence, Aerosol Sci. Tech., 41, 398-417, https://doi.org/10.1080/02786820701199728, 2007.

Moteki, N. and Kondo, Y.: Dependence of laser-induced incandescence on physical properties of black carbon aerosols: measurements and theoretical interpretation, Aerosol Sci. Tech., 44, 663675, https://doi.org/10.1080/02786826.2010.484450, 2010.

Najafi, M. R., Zwiers, F. W., and Gillett, N. P.: Attribution of Arctic temperature change to greenhouse-gas and aerosol influences, Nat. Clim. Change, 5, 246-249, https://doi.org/10.1038/nclimate2524, 2015.

Navarro, J. C. A., Varma, V., Riipinen, I., Seland, Ø., Kirkevåg, A., Struthers, H., Iversen, T., Hansson, H.-C., and Ekman, A. M. L.: Amplification of Arctic warming by past air pollution reductions in Europe, Nat. Geosci., 9, 277-281, https://doi.org/10.1038/ngeo2673, 2016.

Ogren, J. A.: Comment on "Calibration and intercomparison of filter-based measurements of visible light absorption by aerosols", Aerosol Sci. Tech., 44, 589-591, https://doi.org/10.1080/02786826.2010.482111, 2010.

Ogren, J. A., Wendell, J., Andrews, E., and Sheridan, P. J.: Continuous light absorption photometer for long-term studies, Atmos. Meas. Tech., 10, 4805-4818, https://doi.org/10.5194/amt10-4805-2017, 2017.

Pluchino, A. B., Goldberg, S. S., Dowling, J. M., and Randall, C. M: Refractive index measurements of single micron-sized carbon particles, Appl. Optics, 19, 3370-3372, 1980.

Pueschel, R. F. and Kinne, S. A.: Physical and radiative properties of Arctic atmospheric aerosols, Sci. Total Environ., 161, 811-824, 1995.

Qi, L., Li, Q., Henze, D. K., Tseng, H.-L., and He, C.: Sources of springtime surface black carbon in the Arctic: an adjoint analysis for April 2008, Atmos. Chem. Phys., 17, 9697-9716, https://doi.org/10.5194/acp-17-9697-2017, 2017.

Quinn, P. K., Bates, T. S., Baum, E., Doubleday, N., Fiore, A. M., Flanner, M., Fridlind, A., Garrett, T. J., Koch, D., Menon, S., Shindell, D., Stohl, A., and Warren, S. G.: Shortlived pollutants in the Arctic: their climate impact and possible mitigation strategies, Atmos. Chem. Phys., 8, 1723-1735, https://doi.org/10.5194/acp-8-1723-2008, 2008.

Quinn, P. K., Bates, T. S., Schulz, K., and Shaw, G. E.: Decadal trends in aerosol chemical composition at Barrow, Alaska: 1976-2008, Atmos. Chem. Phys., 9, 8883-8888, https://doi.org/10.5194/acp-9-8883-2009, 2009.

Radke, L. F., Lyons, J. H., Hegg, D. A., Hobbs, P. V., and Bailey, I. H.: Airborne observations of Arctic aerosols-I. Characteristics of Arctic haze, Geophys. Res. Lett., 11, 393-396, 1984.

Rahn, K. A.: The Arctic air-sampling network in 1980, Atmos. Environ., 15, 1349-1352, 1981.

Rahn, K. A., Boyrs, R., and Shaw, G. E.: The Asian source of Arctic haze bands, Nature, 268, 713-715, 1977.

Russell, P. B., Bergstrom, R. W., Shinozuka, Y., Clarke, A. D., DeCarlo, P. F., Jimenez, J. L., Livingston, J. M., Redemann, J., Dubovik, O., and Strawa, A.: Absorption Angstrom Exponent in AERONET and related data as an indicator of aerosol composition, Atmos. Chem. Phys., 10, 1155-1169, https://doi.org/10.5194/acp-10-1155-2010, 2010.

Samset, B. H., Myhre, G., Schulz, M., Balkanski, Y., Bauer, S., Berntsen, T. K., Bian, H., Bellouin, N., Diehl, T., Easter, R. C., Ghan, S. J., Iversen, T., Kinne, S., Kirkevåg, A., Lamarque, J.-F.,
Lin, G., Liu, X., Penner, J. E., Seland, Ø., Skeie, R. B., Stier, P., Takemura, T., Tsigaridis, K., and Zhang, K.: Black carbon vertical profiles strongly affect its radiative forcing uncertainty, Atmos. Chem. Phys., 13, 2423-2434, https://doi.org/10.5194/acp13-2423-2013, 2013.

Sand, M., Berntsen, T. K., von Salzen, K., Flanner, M. G., Langner, J., and Victor, D. G: Response of the Arctic temperature to changes in emissions of short-lived climate forcers, Nat. Clim. Chang., 6, 286-289, https://doi.org/10.1038/nclimate2880, 2016.

Schacht, J., Heinold, B., Quaas, J., Backman, J., Cherian, R., Ehrlich, A., Herber, A., Huang, W. T. K., Kondo, Y., Massling, A., Sinha, P. R., Weinzierl, B., Zanatta, M., and Tegen, I.: The importance of the representation of air pollution emissions for the modeled distribution and radiative effects of black carbon in the Arctic, Atmos. Chem. Phys., 19, 11159-11183, https://doi.org/10.5194/acp-19-11159-2019, 2019.

Schmeisser, L., Backman, J., Ogren, J. A., Andrews, E., Asmi, E., Starkweather, S., Uttal, T., Fiebig, M., Sharma, S., Eleftheriadis, K., Vratolis, S., Bergin, M., Tunved, P., and Jefferson, A.: Seasonality of aerosol optical properties in the Arctic, Atmos. Chem. Phys., 18, 11599-11622, https://doi.org/10.5194/acp-18-115992018, 2018.

Schnell, R. C. and Raatz, W. E.: Vertical and horizontal characteristics of Arctic hare during AGASP; Alaskan Arctic, Geophys. Res. Lett., 11, 369-376, 1984.

Schulz, H., Zanatta, M., Bozem, H., Leaitch, W. R., Herber, A. B., Burkart, J., Willis, M. D., Kunkel, D., Hoor, P. M., Abbatt, J. P. D., and Gerdes, R.: High Arctic aircraft measurements characterising black carbon vertical variability in spring and summer, Atmos. Chem. Phys., 19, 2361-2384, https://doi.org/10.5194/acp19-2361-2019, 2019.

Schwarz, J. P., Spackman, J. R., Gao, R. S., Watts, L. A., Stier, P., Schulz, M., Davis, S. M., Wofsy, S. C., and Fahey, D. W.: Global-scale black carbon profiles observed in the remote atmosphere and compared to models, Geophys. Res. Lett., 37, L18812, https://doi.org/10.1029/2010GL044372, 2010.

Sirois, A. and Barrie, L. A.: Arctic lower tropospheric aerosol trends and composition at Alert, Canada: 1980-1995, J. Geophys. Res., 104, 11599-11618, https://doi.org/10.1029/1999JD900077, 1999.

Sharma, S., Lavoue, D., Cachier, H., Barrie, L. A., and Gong, S. L.: Long-term trends of the black carbon concentrations in the Canadian Arctic, J. Geophys. Res., 109, D15203, https://doi.org/10.1029/2003JD004331, 2004.

Sharma, S., Andrews, E., Barrie, L. A., Ogren, J. A., and Lavoué, D.: Variations and sources of the equivalent black carbon in the high Arctic revealed by long-term observations at Alert and Barrow: 1989-2003, J. Geophys. Res., 111, D14208, https://doi.org/10.1029/2005JD006581, 2006.

Sharma, S., Ishizawa, M., Chan, D., Lavoué, D., Andrews, E., Eleftheriadis, K., and Maksyutov, S.: 16-Year simulation of Arctic black carbon: Transport, source contribution, and sensitivity analysis on deposition, J. Geophys. Res., 118, 943-964, https://doi.org/10.1029/2012JD017774, 2013.

Sharma, S., Leaitch, W. R., Huang, L., Veber, D., Kolonjari, F., Zhang, W., Hanna, S. J., Bertram, A. K., and Ogren, J. A.: An evaluation of three methods for measuring black carbon in Alert, Canada, Atmos. Chem. Phys., 17, 15225-15243, https://doi.org/10.5194/acp-17-15225-2017, 2017. 
Sharma, S., Barrie, L. A., Magnusson, E., Brattström, G., Leaitch, W. R., Steffen, A., and Landsberger, S.: A factor and trends analysis of multidecadal lower tropospheric observations of Arctic aerosol composition, black carbon, ozone, and mercury at Alert, Canada, J. Geophys. Res.-Atmos., 124, 14133-14161, https://doi.org/10.1029/2019JD030844, 2019.

Shaw, G. E.: Evidence for a central Eurasian source area of Arctic haze in Alaska, Nature, 299, 815-818, 1983.

Sherman, J. P., Sheridan, P. J., Ogren, J. A., Andrews, E., Hageman, D., Schmeisser, L., Jefferson, A., and Sharma, S.: A multi-year study of lower tropospheric aerosol variability and systematic relationships from four North American regions, Atmos. Chem. Phys., 15, 12487-12517, https://doi.org/10.5194/acp-15-124872015, 2015.

Shindell, D. and Faluvegi, G.: Climate response to regional radiative forcing in the twentieth century, Nat. Geosci., 2, 294-300, https://doi.org/10.1038/NGEO473, 2009.

Sinha, P. R., Kondo, Y., Koike, M., Ogren, J. A., Jefferson, A., Barrett, T. E., Sheesley, R. J., Ohata, S., Moteki, N., Coe, H., Liu, D., Irwin, M., Tunved, P., Quinn, P. K., and Zhao, Y.: Evaluation of ground-based black carbon measurements by filter-based photometers at two Arctic sites, J. Geophys. Res.-Atmos., 122, 3544-3572, https://doi.org/10.1002/2016JD025843, 2017.

Slowik, J. G., Cross, E. S., Han, J.-H., Davidovits, P., Onasch, T. B., Jayne, J. T., Williams, L. R., Canagaratna, M. R., Worsnop, D. R., Chakrabarty, R. K., Moosmüller, H., Arnott, W. P., Schwarz, J. P., Gao, R.-S., Fahey, D. W., Kok, G. L., and Petzold, A.: An inter-comparison of instruments measuring black carbon content of soot particles, Aerosol Sci. Tech., 41, 295-314, https://doi.org/10.1080/02786820701197078, 2007.

Sobhani, N., Kulkarni, S., and Carmichael, G. R.: Source sector and region contributions to black carbon and $\mathrm{PM}_{2.5}$ in the Arctic, Atmos. Chem. Phys., 18, 18123-18148, https://doi.org/10.5194/acp-18-18123-2018, 2018.

Spackman, J. R., Gao, R. S., Neff, W. D., Schwarz, J. P., Watts, L. A., Fahey, D. W., Holloway, J. S., Ryerson, T. B., Peischl, J., and Brock, C. A.: Aircraft observations of enhancement and depletion of black carbon mass in the springtime Arctic, Atmos. Chem. Phys., 10, 9667-9680, https://doi.org/10.5194/acp10-9667-2010, 2010.

Staebler, R. M., den Hartog, G., Georgi, B., and Düsterdiek, T.: Aerosol size distributions in Arctic haze during the POLAR Sunrise Experiment 1992, J. Geophys. Res., 99, 25429-25437, 1994.

Stohl, A., Aamaas, B., Amann, M., Baker, L. H., Bellouin, N., Berntsen, T. K., Boucher, O., Cherian, R., Collins, W., Daskalakis, N., Dusinska, M., Eckhardt, S., Fuglestvedt, J. S., Harju, M., Heyes, C., Hodnebrog, Ø., Hao, J., Im, U., Kanakidou, M., Klimont, Z., Kupiainen, K., Law, K. S., Lund, M. T., Maas, R., MacIntosh, C. R., Myhre, G., Myriokefalitakis, S., Olivié, D., Quaas, J., Quennehen, B., Raut, J.-C., Rumbold, S. T., Samset, B. H., Schulz, M., Seland, Ø., Shine, K. P., Skeie, R. B., Wang, S., Yttri, K. E., and Zhu, T.: Evaluating the climate and air quality impacts of short-lived pollutants, Atmos. Chem. Phys., 15, 10529-10566, https://doi.org/10.5194/acp-15-105292015, 2015.

Targino, A. C., Noone, K. J., and Ostrom, E.: Airborne in-situ characterization of dry aerosol optical properties in a multisource influenced marine region, Tellus B, 57, 247-260, 2005.
Valero, F. P. J., Ackerman, T. P., and Gore, J. Y.: The absorption of solar radiation by the Arctic atmosphere during the haze season and its effects on the radiation balance, Geophys. Res. Lett., 11, 465-468, 1984.

Valero, F. P. J., Ackerman, T. P., and Gore, W. J. R.: The effects of the arctic haze as determined from airborne radiometric measurements during AGASP II, J. Atmos. Chem., 9, 225-244, 1989.

van Donkelaar, A., Martin, R. V., Leaitch, W. R., Macdonald, A. M., Walker, T. W., Streets, D. G., Zhang, Q., Dunlea, E. J., Jimenez, J. L., Dibb, J. E., Huey, L. G., Weber, R., and Andreae, M. O.: Analysis of aircraft and satellite measurements from the Intercontinental Chemical Transport Experiment (INTEX-B) to quantify long-range transport of East Asian sulfur to Canada, Atmos. Chem. Phys., 8, 2999-3014, https://doi.org/10.5194/acp-8-29992008, 2008.

Wiedinmyer, C., Akagi, S. K., Yokelson, R. J., Emmons, L. K., AlSaadi, J. A., Orlando, J. J., and Soja, A. J.: The Fire INventory from NCAR (FINN): a high resolution global model to estimate the emissions from open burning, Geosci. Model Dev., 4, 625641, https://doi.org/10.5194/gmd-4-625-2011, 2011.

Willis, M. D., Bozem, H., Kunkel, D., Lee, A. K. Y., Schulz, H., Burkart, J., Aliabadi, A. A., Herber, A. B., Leaitch, W. R., and Abbatt, J. P. D.: Aircraft-based measurements of High Arctic springtime aerosol show evidence for vertically varying sources, transport and composition, Atmos. Chem. Phys., 19, 57-76, https://doi.org/10.5194/acp-19-57-2019, 2019.

Wofsy, S. C.: The HIPPO science team and cooperating modellers and satellite teams: HIAPER Pole-to-Pole Observations (HIPPO): fine-grained, global-scale measurements of climatically important atmospheric gases and aerosols, Philos. T. R. Soc. A, 369, 2073-2086, https://doi.org/10.1098/rsta.2010.0313, 2011.

Xu, J.-W., Martin, R. V., Morrow, A., Sharma, S., Huang, L., Leaitch, W. R., Burkart, J., Schulz, H., Zanatta, M., Willis, M. D., Henze, D. K., Lee, C. J., Herber, A. B., and Abbatt, J. P. D.: Source attribution of Arctic black carbon constrained by aircraft and surface measurements, Atmos. Chem. Phys., 17, 1197111989, https://doi.org/10.5194/acp-17-11971-2017, 2017.

Yu, H., Li, W., Zhang, Y., Tunved, P., Dall'Osto, M., Shen, X., Sun, J., Zhang, X., Zhang, J., and Shi, Z.: Organic coating on sulfate and soot particles during late summer in the Svalbard Archipelago, Atmos. Chem. Phys., 19, 10433-10446, https://doi.org/10.5194/acp-19-10433-2019, 2019.

Zanatta, M., Laj, P., Gysel, M., Baltensperger, U., Vratolis, S., Eleftheriadis, K., Kondo, Y., Dubuisson, P., Winiarek, V., Kazadzis, S., Tunved, P., and Jacobi, H.-W.: Effects of mixing state on optical and radiative properties of black carbon in the European Arctic, Atmos. Chem. Phys., 18, 14037-14057, https://doi.org/10.5194/acp-18-14037-2018, 2018.

Zender, C. S.: Mineral Dust Entrainment and Deposition (DEAD) model: Description and 1990s dust climatology, J. Geophys. Res., 108, 4416, https://doi.org/10.1029/2002JD002775, 2003.

Zobrist, B., Marcolli, C., Pedernera, D. A., and Koop, T.: Do atmospheric aerosols form glasses?, Atmos. Chem. Phys., 8, 52215244, https://doi.org/10.5194/acp-8-5221-2008, 2008. 